See discussions, stats, and author profiles for this publication at: https://www.researchgate.net/publication/337942093

\title{
Fen Bilimleri Öğretmen Adaylarının Argümantasyon Destekli Araştırma Sorgulamaya Dayalı Öğretim Yeterliklerinin Geliştirilmesi
}

Article · December 2019

Dol: 10.17051/ilkonline.2019.639402

\section{CITATIONS}

0

2 authors, including:

Tuğba Ecevit

Hacettepe University

16 PUBLICATIONS 14 CITATIONS

SEE PROFILE

Some of the authors of this publication are also working on these related projects:

READS

43

Project $\quad$ ARGÜMANTASYON DESTEKLI ARAŞTIRMA-SORGULAMAYA DAYALI ÖĞRETIMM UYGULAMALARININ FEN ÖĞRETMEN EĞiTiMINDDEKI ETKILILILĞi View project 


\title{
Fen Bilimleri Öğretmen Adaylarının Argümantasyon Destekli Araştırma Sorgulamaya Dayalı Öğretim Yeterliklerinin Geliştirilmesi ${ }^{1}$
}

\section{Improvement of Argumentation Based Inquiry Science Teaching Competencies of Pre-service Science Teachers}

\author{
Tuğba Ecevit, Hacettepe Üniversitesi, tubaecevit@hacettepe.edu.tr ORCID: 0000-0002-5119-9828 \\ Fitnat Kaptan, Hacettepe Üniversitesi, fitnat@hacettepe.edu.tr ORCID: 0000-0002-8498-729X
}

\begin{abstract}
Öz. Bu araştırmada, fen bilimleri öğretmen adaylarının argümantasyon destekli araştırma sorgulamaya dayalı öğretim yeterliklerinin geliştirilmesi amaçlanmıştır. Araştırma kapsamında argümantasyon destekli araştırma sorgulamaya dayalı uygulamaların fen bilimleri öğretmen adaylarının öğretmeöğrenme anlayışlarına ve deney tasarlama becerilerine etkisi araştırılmıştır. Karma yöntem araștırmalarından eş zamanlı üçgenleme deseninin kullanıldığı bu araştırmada nicel yöntem boyutunda "tek grup ön-test son-test zayıf deneysel desen" nitel yöntem boyutunda ise "durum çalışması deseni" kullanılmıştır. Araştırma 2016-2017 eğitim-öğretim yılı güz döneminde "fen okuryazarlığı" seçmeli dersini seçen 38 öğretmen adayı ile 14 hafta boyunca yürütülmüştür. Veri toplama aracı olarak öğretmeöğrenme anlayışları ölçeği, deney tasarlama kâğıtları ve öz-değerlendirmeleri, yarı-yapılandırılmış görüşme formu ve yansıtıcı değerlendirme yazıları kullanılmıştır. Araştırma sonucunda elde edilen nicel bulgular her ne kadar öğretmen adaylarının öğretme-öğrenme anlayışlarında radikal değişim olmadığını ortaya koysa da elde edilen nitel bulgular yapılan uygulamaların öğretmen adaylarının deney tasarlama becerilerini geliştirdiğini, bilimsel süreç becerilerinin öğretimine yönelik farkındalık oluşturduğunu, deney tasarlamalarında açık uçlu araştırma sorgulamaya yönelik bir değişim yaşadıklarını, öğretmeöğrenme anlayışlarında bir takım değişikliğe ve farkındalığa neden olduğunu göstermektedir.
\end{abstract}

Anahtar Sözcükler: Araştırma sorgulamaya dayalı öğrenme, argümantasyona dayalı öğrenme, bilimsel süreç becerilerinin öğretimi, deney tasarlama becerisi, fen bilimleri öğretmen eğitimi.

\begin{abstract}
The aim of the study is the improvement of argumentation based inquiry science teaching competencies of pre-service science teachers. In this study, the effects of argumentation-based inquiry teaching practices on teaching-learning conception and the ability to design experiments of the preservice teacher were investigated. "Concurrent triangulation design" was used as mixed research method. The study was carried out for 14 weeks with 38 pre-service teachers who selected "Science Literacy" course for 2016-2017 academic years. Teaching-learning conception scale, experiment design studies and self-evaluations, semi-structured interview and reflective evaluation forms were used as the data collection tools. Although the quantitative findings reveal that there is no radical change in the teaching-learning conceptions of the pre-service teachers, the qualitative findings obtained showed that the pre-service teachers' improved experiment design skills and created awareness about the teaching of scientific process skills. It also showed that pre-service teachers experienced a change towards an openended inquiry in experimental designs and this led to a number of changes and awareness in teachinglearning conception.
\end{abstract}

Keywords: Argumentation based learning, design experiment skills, inquiry based learning, science teacher education, teaching of scientific process skills.

${ }^{1}$ Bu makale, birinci yazarın ikinci yazar danışmanlığında hazırladığı doktora tezinden üretilmiştir. 


\section{SUMMARY}

\section{Introduction}

Science course teaching program is being updated for the purpose of educating science literate individuals (Ministry of National Education [MNE], 2013; 2018). However, more emphasis must be given to educating science teachers in order to change teaching program to be implemented as targeted and to reveal the learning outcomes (Demirel, 2005). In order for the science course teaching program to be effective and successful, pre-service and in-service teacher trainings should be based on practice. pre-service teachers need to gain practical skills. To make students qualified science literate individuals, it is of great importance to develop argumentation based inquiry science teaching competencies of pre-service science teachers. The qualifications of effective science teachers include the ability to plan and conduct inquiry based experiment. The fact that pre-service teachers have conducted various experiments during their undergraduate education will help them to teach the science more effectively. In many studies, it has been revealed that the experiences of pre-service teachers as a student can affect teaching-learning conceptions (Koballa, Glynn, Leslie and Coleman, 2005).

In this study, it is aimed to improve argumentation based inquiry teaching competencies by experiencing pre-service teachers' argumentation based inquiry teaching practices. In this context, the research problem focuses on two basic situations.

1. What is the effect of argumentation based inquiry teaching practices on the teachinglearning conceptions of pre-service teachers? What kind of similarities or differences are there between qualitative and quantitative data?

2. How did pre-service teachers design experiments before and after argumentation based inquiry teaching practices?

2a. What are the similarities and differences in experimental designs of pre-service teachers before and after practice?

2b. How do pre-service teachers assess their self-assessment in experimental design?

In this study, it is aimed that pre-service teachers learn argumentation based inquiry practices by experiencing them so that they feel sufficient to make such activities to their students when they become teachers.

\section{Method}

"Concurrent triangulation design" was used as mixed research method (Creswell, 2009). The quantitative part of study was designed as "one group pretest-posttest poor experimental design" (Freankel, Wallen and Hyun, 2012); whereas the qualitative part designed as "a case study" (Merriam, 2009). The study group consisted of 38 pre-service teachers who selected the course of "science literacy" at the division of science education. The study group was determined using convenient sampling method (Fraenkel, Wallen and Hyun, 2012). $45 \%$ of pre-service teachers are in the 2 nd grade, $42 \%$ in the 3 rd grade and $13 \%$ in the 4 th grade. 34 of pre-service teachers are female and 4 of them are male.In this study conducted as a mixed research method, quantitative and qualitative data collection tools were used. Teaching-learning conception scale, experiment design studies and self-evaluations, semi-structured interview and reflective evaluation forms were used as the data collection tools.In the analysis of quantitative data descriptive and predictive statistical methods were used, while in the analysis of qualitative data descriptive and content analysis methods were used.The study was conducted in a public university in Ankara during 2016-2017 academic years. In the undergraduate program of science education, in the elective course of "Science Literacy" three hours a week with 38 preservice teachers argumentation based inquiry practices were conducted. During the implementation process, it was ensured that pre-service teachers designed, conducted, reported, shared, discussed and evaluated argumentation based inquiry activities that they could use in their classrooms by doing group work. 


\section{Results}

According to the results of descriptive statistics, pre-service teachers have more constructivist conceptions $(X=4.67)$ than traditional teaching-learning conceptions $(X=2.74)$. After the practices, it was concluded that the mean of constructivist conception points increased $(X=$ $4.72)$ and the average of traditional conception points decreased $(X=2.21)$. However, it can be said that there is no statistically significant difference between pre and post-test scores, $z=$ $1.14 ; p>0.05$. During the interviews, pre-service teachers stated that the practices were teaching how to teach, be prepared to be a teacher, and that science teaching improved selfefficacy beliefs. According to Blkmaz (2017), pre-service teachers supported the constructivist conceptions but on the other hand, they tend to have traditional conceptions. In this context, the findings obtained from semi-structured interviews and documents are thought to reveal the preservice teachers better in the improvement of teaching-learning conceptions. During the interviews, pre-service teachers stated that they improved their skills in designing teachinglearning processes, they learned to teach, be prepared to be teachers and science teaching improved their self-efficacy beliefs. In addition, pre-service teachers explained the change in their teaching-learning conceptions by giving examples from previous learning experiences. It was determined that prior to the practices pre-service teachers designed closed-ended experiment with step by step instructions, then after the practices they designed an open-ended experiment which are argumentation based and inquiry based. As a result, the argumentation based inquiry teaching practices conducted for 14 weeks have created awareness of pre-service teachers in teaching scientific process skills. It was determined that pre-service teachers experienced a change towards an open-ended inquiry in experimental design. In conclusion thanks to practices, it can be said that pre-service teachers improved argumentation based inquiry teaching competencies.

\section{Gíriș}

Teknolojinin hızla geliştiği dördüncü sanayi devriminin yaşandığı 21. yüzyılda gelişmiş ülkeler arasında yer alabilmek için ülkemizde fen eğitimine verilen önem her geçen gün artmaktadır. Aslında 20. yüzyılın ikinci yarısından itibaren fen eğitimine verilen önemin arttığı görülmektedir. Gelişmiş ve gelişmekte olan ülkeler ekonomik alanda birbiriyle olan liderlik yarışını sürdürebilmeleri için eğitim alanında yeni standart geliştirme çabaları içerisine girmişlerdir. Özellikle 1957 yılında Rusya'nın Sputnik 1 adlı ilk yapay uyduyu uzaya göndermesi üzerine Amerika ve İngiltere'deki eğitimciler, okullarda verilen fen eğitiminin kalitesini sorgulamaya başlamış ve fen öğretimi programlarını yenileme sürecine girmişlerdir. $\mathrm{Bu}$ çalışmaların ilk ürünleri Amerika'da "Physical Science Study Commitee", "Chem Study", "Biyological Science Curriculum Study" ve İngiltere'de ise "Nuffield" olarak bilinmektedir. Fen bilimleri öğretim programı yenileme çalışmaları hızla dünyanın diğer ülkelerine de yayılmıştır. 20. yüzyılın sonlarına gelindiğinde Amerikan Fen Eğitimi Geliştirme Komisyonu (American Association for the Advancement of Science [AAAS]) ulusal düzeyde bir bilimsel okuryazarlık seviyesine ulaşmak ve bilimsel okuryazarlık ölçütlerini belirlemek amacıyla geniş çaplı ve çok yönlü bir çalışma olan "Proje 2061" adını verdiği bir projeye başlamıştır. Bu proje kapsamında 1990 yılında "Science for All Americans-Bütün Amerikalılar için Fen" ve 1993 yılında "Benchmarks For Scientific Literacy-Bilimsel Okuryazarlık Standartları" çalışmaları yayımlanmıştır. Amerikan Ulusal Araştırma Konseyi (National Research Council [NRC]) 1996 yılında "National Science Education Standards-Ulusal Fen Eğitim Standartları" ile 2000 yılında "Inquiry and the National Science Education-Araştırma sorgulama ve Amerikan Ulusal Fen Eğitimi Standartları" çalışmalarını yayımlamıştır. Bu çalışmalarda öğrencilerin bilimsel okuryazar olabilmeleri için hangi yeterlik ve anlayışa sahip olmaları gerektiği, bu yeterliklerin kazandırılması için nasıl bir öğrenme ve öğretme ortamı oluşturulması gerektiği gibi konulara 
yer verilmiştir. Bu çalışmalarda bilimsel okuryazar bireyler yetiştirebilmek için "araştırma sorgulamaya dayalı öğrenme" yaklaşımının kullanılması gerektiği vurgulanmaktadır.

Bilimsel okuryazarlığın tek bir tanımı söz konusu olmayıp çeşitli bilgi, beceri ve anlayışları içeren çok yönlü bir kavram olarak ele alınmaktadır (Bybee, 1997; DeBoer, 2000; Matthews, 1994). Bilim okuryazarı olan birey, doğal dünya ile ilgili bilimsel açıklamaları bilir, kullanır ve yorumlar; bilimsel kanıtlar, açıklamalar üretir ve değerlendirir; bilimsel bilginin doğasını ve gelişimini anlar; bilimsel uygulamalara ve tartışmalara üretken bir biçimde katılır (Duschl, Schweingeuber ve Shouse, 2007; NRC, 2000). Araştırma sorgulamaya dayalı öğrenme bilimin nasıl yapıldığını öğretmeye yönelik süreç odaklı bir öğretim yaklaşımıdır. Öğrenciler araştırma sorgulamaya dayalı öğrenme sürecinde sorular sorarak, deney ve gözlemler yaparak, gözlemlerine dayalı açıklamalar oluşturarak, çeşitli iletişim yollarını kullanarak sürecin her aşamasında öğrenmenin sorumluluğunu alır ve yaparak-yaşayarak-düșünerek öğrenir. $\mathrm{Bu}$ yaklaşım öğrencinin neyi öğrendiğini, neyi öğrenmediğini farkına varmasına yardımcı olur (NRC, 1996; 2000).

Ülkemizde cumhuriyetin ilanından günümüze kadar 1926, 1936, 1948, 1968, 1972, 1974, 1992, 2000, 2005, 2013, 2018 yıllarında fen öğretim programları değişmiştir (Gücüm ve Kaptan, 1992; MEB, 2000, 2005, 2013, 2018). 2004 yılına kadar davranışçı öğrenme yaklaşımın etkisiyle ülkemizde öğrencinin bilginin alıcısı ve depolayıcısı olduğu, öğretmenin ise bilginin sunucusu olduğu geleneksel öğrenme yaklaşımı olarak adlandırılan öğretmen merkezli bir anlayış hâkimdi. Fen eğitiminde yapılan reformlar ışığında 2005 yılında büyük değişime gidilerek Fen ve Teknoloji Öğretim Programının temel felsefesi ilerlemecilik olarak değiștirilmiştir ve öğrenci merkezli olan yapılandırmacı öğrenme yaklaşımı temel alınmıştır (MEB, 2005). 2013 yılında Fen Bilimleri Dersi Öğretim Programının temel felsefesi ilerlemeciliktir ve öğrenci merkezli olan araștırma sorgulamaya dayalı öğrenme yaklaşımı temel alınmıştır (MEB, 2013). Son olarak, 2018 yllında yeniden güncellenen Fen Bilimleri Dersi Öğretim Programının temel felsefesi faydacılık olarak revize edilmiştir ve öğrenciyi merkeze alan sosyal yapılandırmacı bir anlayıș temel alınmıştır (MEB, 2018). Fen eğitim programlarında öğretmen merkezli anlayıştan öğrenci merkezli anlayışa doğru radikal bir değişim ve gelişim yaşanmaktadır. Bu doğrultuda öğrenmeöğretme ortamlarının düzenlenmesi önerilmektedir. Fakat öğretmen ve öğretmen adaylarının büyük çoğunluğu eğitim hayatlarının bir kısmında öğretmen merkezli anlayış ile öğrenim gördüklerinden dolayı çoğu zaman yapılandırmacı anlayışı desteklediklerini söylemelerine rağmen geleneksel anlayışa da meyil etmeye devam etmektedir (Bıkmaz, 2017). Alanyazın incelendiğinde öğretmenlerin öğretmen merkezli geleneksel öğretme-öğrenme yaklaşımlarını kullanmaya devam ettiklerini (Geçer ve Özel, 2012; Küçüköner, 2011; Newton, Driver ve Osborne, 1999; Şimsek, Hırça ve Çoşkun, 2012) gösteren pek çok araştırmaya rastlanmıştır. Ayrıca öğretmenlerin araştırma sorgulamaya dayalı öğrenme yaklaşımını sınıflarında yeteri kadar uygulayamadıklarını ve uygulamaları sırasında çeşitli sorunlar yaşadığı (Bayram, 2015; Capps, Crowford ve Epstein, 2010; Kaya ve Böyük, 2011; Yoon, Joung ve Kim, 2012) tespit eden pek çok araştırma vardır. Hatta öğretmenlerin argümantasyon ve araştırma sorgulamaya dayalı uygulama süreci hakkında yeterli bilgiye sahip olmadıklarını gösteren (Erduran ve JimenezAleizandre, 2007; Driver, Newton ve Osborne, 2000) araştırmalar yer almaktadır. Aynı zamanda değişen öğrenme-öğretme yaklaşımlarına yönelik verilen hizmet içi eğitimlerin yetersiz olduğunu, mesleki deneyim kazandıramadığını (Akıncı, Uzun ve Kışoğlu, 2015; Aydın ve Çakıroğlu, 2010)belirten araştırmalar da bulunmaktadır. NRC'ye (1996) göre “... hizmet öncesi ve hizmet içi eğitimler öğretmenleri aktif öğrenmeye katan, bilgi, anlayış ve beceri geliştiren deneyimler içermelidir. Öğretmenlerin kendileri bunu hiç deneyimlemediyse standartlarda tanımlanan bilim ve bilimin nası öğrenildiği ile ilgili vizyonun okullarda öğrencilere aktarması neredeyse imkânsız olacaktır" (s.56). Smith ve Anderson (1999) öğretmen adaylarına genellikle bilimsel uygulamalar ve tartışmalara katılma fırsatları verilmediğini, öğretmen adaylarının öğretmen olduklarında öğrencilerini bilimsel uygulamalara ve diyaloglara katabilmesi için öncelikle kendilerinin bu uygulamalara ve diyaloglara katılması gerektiğini vurgulamıştır. Öğretmenlerin ve öğretmen adaylarının mesleki gelişimlerine katkı sağlamak için yapılan uygulamaların öğretmenlerin bilgi, beceri ve duyuş öğrenme alanlarının gelişmesine katkı 
sağlayacak bizzat kendilerinin yaparak yaşayarak deneyimleyebileceği uygulamaları içermelidir (Driver vd., 2000).

\section{Araştırmanın Önemi ve Amacı}

Görüldüğü gibi nitelikli fen okuryazarı bireyler yetiştirmek amacıyla Fen Bilimleri Dersi Öğretim Programı güncellenmektedir (MEB, 2013; 2018). Ancak değișen öğretim programının hedeflendiği gibi uygulanabilmesi ve hedeflenen öğrenme çıtıllarını ortaya koyabilmesi için nitelikli fen bilimleri öğretmenlerinin yetiştirilmesine daha fazla önem verilmesi gerekmektedir (Demirel, 2005). Bu bağlamda Fen Bilimleri Dersi Öğretim Programı'nın etkili ve başarılı olabilmesi için hizmet öncesi ve hizmet içi öğretmen eğitimlerinin uygulamaya dayalı olması ve öğretmen adaylarının pratik anlamda beceri kazanmasına ihtiyaç vardır.

Öğrencilerin nitelikli fen okuryazarı bireyler olarak yetiştirilebilmesi için öğretmen adaylarının eğitiminde argümantasyon ve araștırma sorgulamaya dayalı öğretim yeterliklerinin geliştirilmesi büyük önem arz etmektedir. Etkili fen bilimleri öğretmenlerinin nitelikleri arasında araştırma sorgulamaya dayalı deneysel araştırmaları planlayabilme ve güvenli bir şekilde yürütebilme becerilerine sahip olmaları yer almaktadır. Öğretmen adayları lisans eğitimlerini tamamlamadan önce ilkokul ve ortaokul seviyelerinde yaptıracakları deneyleri kendilerinin bizzat uygulamış olmaları fen bilimlerini daha etkin bir şekilde öğretmelerine yardımcı olacaktır. Birçok araştırmada öğretmen adaylarının öğrenci olarak yaşadıkları deneyimlerin öğretme-öğrenme anlayışlarını etkileyebileceğini ortaya koymuştur (Driver vd., 2000; Koballa, Glynn, Leslie ve Coleman, 2005).

$\mathrm{Bu}$ araştırmada, fen bilimleri öğretmen adaylarının argümantasyon destekli araştırma sorgulamaya dayalı öğretim uygulamalarını yaparak yaşayarak deneyimleri sağlanarak argümantasyon destekli araștırma sorgulamaya dayalı öğretim yeterliklerinin geliștirilmesi amaçlanmıştır. Bu kapsamda araştırma problemi iki temel duruma odaklanmaktadır.

1. Argümantasyon destekli araştırma sorgulamaya dayalı öğretim uygulamalarının öğretmen adaylarının öğretme-öğrenme anlayışları üzerine etkisi nedir? Nitel ve nicel veriler arasında nasıl benzerlik ve farklılıklar vardır?

2. Argümantasyon destekli araștırma sorgulamaya dayalı öğretim uygulamaları öncesinde ve sonrasında fen bilimleri öğretmen adaylarının deney tasarlamaları nasıldır?

2a. Uygulama sonrasında deney tasarlamalarında ne tür benzerlikler ve farklılıklar vardır?

2b. Öğretmen adaylarının deney tasarlama sürecindeki öz-değerlendirmeleri nasıldır?

$\mathrm{Bu}$ çalışmada, öğretmen adaylarının argümantasyon destekli araştırma sorgulamaya dayalı uygulamaları bizzat yaparak yaşayarak öğrenmesi böylelikle öğretmen oldukları zaman öğrencilerine bu tarz etkinlikler yaptırmak için kendilerini yeterli hissetmesi hedeflenmektedir.

\section{YÖNTEM}

Fen bilimleri öğretmen adaylarının argümantasyon destekli araştırma sorgulamaya dayalı öğretim yeterliklerinin geliştirilmesinin amaçlandığı bu araştırmada karma yöntem araştırmalarından "eş zamanlı üçgenleme deseni" kullanılmıştır (Creswell, 2009). Çalışmada "tek grup ön-test son-test zayıf deneysel desen" (Freankel, Wallen ve Hyun, 2012); ile "durum çalışması deseni" (Merriam, 2009) eş zamanlı olarak kullanılmıştır.

\section{Çalışma Grubu ve Özellikleri}

Araştırmanın çalışma grubunu Ankara'da bulunan bir devlet üniversitesinin fen bilimleri öğretmenliği lisans programında "fen okuryazarlığı" seçmeli dersini alan 38 öğretmen adayı olușturmaktadır. Çalıșma grubu uygun örnekleme yöntemi kullanılarak belirlenmiștir (Fraenkel, Wallen ve Hyun, 2012). Çalışma grubundaki öğretmen adaylarının \% 45'i 2. sınıf, \% 42'si 3. sınıf ve \% 13'ü ise 4. sınıfta öğrenim görmekte olup öğretmen adaylarının 34'ü kadın, 4'ü ise erkektir. 


\section{Veri Toplama Araçları}

Karma yöntem araştırması olarak yürütülen bu araştırmada nicel ve nitel veri toplama araçları kullanılmıştır.

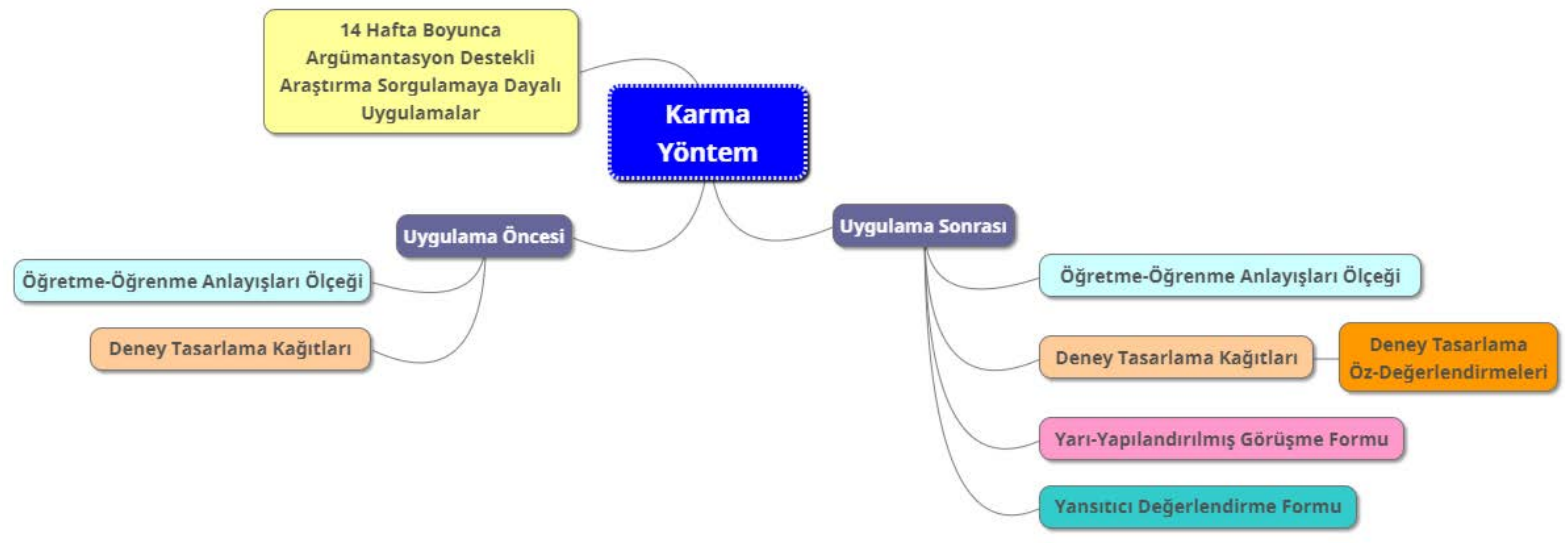

ŞEKIL 1. Uygulama öncesi ve sonrasında kullanılan veri toplama araçlarının zihin haritasında gösterimi

Öğretme-öğrenme anlayışları ölçeği. Öğretmen adaylarının öğretme ve öğrenme anlayışlarını belirlemek üzere Chan ve Elliot (2004) tarafından geliştirilen Aypay (2011) tarafından Türkçe'ye uyarlanması ve geçerlik ve güvenirlik çalışması yapılan "Öğretme ve Öğrenme Anlayışları Ölçeği" kullanılmıştır. Ölçek 5'li Likert tipi formatında 30 maddeden oluşmaktadır ve iki alt boyutu vardır. Likert tipi ölçekte, kesinlikle katılıyorum (5 puan), katılıyorum (4 puan), kararsızım (3 puan), katılmıyorum (2 puan), kesinlikle katılmıyorum (1 puan) olarak kodlanmıştır. Yapılandırmacı anlayıșı boyutu 12 madde, geleneksel anlayış boyutu ise 18 maddeden oluşmaktadır. Aypay (2011) ölçeğin geneli için güvenirlik katsayısını .71 olarak hesaplamış ve kullanılabilir olduğunu tespit etmiştir. Yapılandırmacı anlayıș boyutuna ait güvenirlik katsayısını .88 ve geleneksel anlayış boyutuna ait güvenirlik katsayısını .83 olarak belirlemiştir. $\mathrm{Bu}$ çalışmada ölçeğin geneli için güvenirlik katsayısı .88 olarak, yapılandırmacı anlayış boyutuna ait güvenilirlik katsayısı .86 olarak ve geleneksel anlayış boyutuna ait güvenirlik kayısı ise .91 olarak hesaplanmıştır.

Deney tasarlama kâğıtları ve öz-değerlendirmeleri. Uygulama öncesinde ve sonrasında öğretmen adaylarının deney tasarlama yaklaşımlarını ve bu süreçte kullanmayı hedefledikleri bilimsel süreç becerilerini belirlemek amacıyla sıvıların kaynama noktası ile ilgili bir deney tasarlamaları istenmiştir. Öğretmen adaylarına "sıvıların kaynama noktası, sıvıda çözünmüş katı madde miktarı arttıkça artar" hipotezi verilerek bu hipotezi test etmek için nasıl bir deney tasarlarsınız? Tasarlayacakları deneyin bütün ayrıntılarını ve nasıl yapacaklarını yazarak açıllamaları istenmiştir. Uygulama sonrasında, öğretmen adaylarından uygulama öncesi ve sonrası deney tasarlama çalışmalarındaki benzerlik ve farklılıkları değerlendirmeleri istenmiştir.

Yarı yapılandırılmış görüşme formu. Uygulama sonrasında öğretmen adaylarıyla yarı yapılandırılmış görüşmeler yapılmıştır. Görüşme soruları araştırmacı tarafından öncelikle taslak form halinde hazırlanmıştır. Taslak yarı-yapılandırılmış görüşme formunun geliştirilmesi için fen eğitimi ve nitel araştırma uzmanlarına başvurulmuştur. Alan uzmanlarından geribildirimler doğrultusunda düzeltmeler yapıldıktan sonra son hali verilmiştir. Görüşme yapılacak öğretmen adayları gönüllük esasına dayalı olarak belirlenmiştir. Gönüllü olan 14 öğretmen adayı ile bireysel olarak yarı yapılandırılmış görüşmeler yapılmıştır. Görüşmeler bölümün toplantı odasında yapılmıştır ve her bir görüşme yaklaşık olarak 20-25 dakika kadar sürmüştür. Görüşmeler etik kurallar gereğince öğretmen adayının izni doğrultusunda ses kayıt cihazı kullanılarak kayıt edilmiştir. 
Yansıtıcı değerlendirme formu. Uygulama sonrasında öğretmen adaylarının ders hakkındaki görüşlerini belirlemek amacıyla yansıtıcı değerlendirme formu hazırlanmıştır. Hazırlanan form bir dönem boyunca argümantasyon destekli araștırma sorgulamaya dayalı uygulamalarla işlenen "fen okuryazarlığı" dersi hakkında 7 açık uçlu sorudan oluşmaktadır.

\section{Verilerin Analizi}

Karma yöntem araştırması olarak yürütülen bu araştırmada hem nicel hem de nitel veriler elde edilmiștir. Nicel verilerin analizinde betimsel ve yordayıcı istatistik yöntemleri, nitel verilerin analizde ise betimsel ve içerik analizi yöntemleri kullanılarak analiz edilmiştir. Bu araştırmada nicel yöntemlerle elde edilen sonuçlar ile nitel yöntemlerle elde edilen sonuçların birbirini onaylamasını, doğrulamasını sağlamak amacıyla yöntem çeşitlemesi (methodological triangulation) yapılmıştır (Miles ve Huberman, 1994). Böylelikle elde edilen sonuçlar daha zengin ve ayrıntılı hale getirilerek sunulmuştur.

Elde edilen nicel verilerin analizinde SPSS 22 İstatistik Programı kullanılmıştır. Öncelikle verilerin normal dağılıma uygun olup olmadığını belirlenmek amacıyla normallik testleri yapılmıştır. Yapılan testler sonucunda verilerin normal dağılım göstermediği belirlenmiştir. Ön test ve son test arasında anlamlı bir farkın olup olmadığını belirlemek için non-parametrik testlerden "ilişkili ölçümler için wilcoxon işaretli sıralılar testi" kullanılmıştır.

Yarı yapılandırılmış görüşmelerden elde edilen ses kayıtları öncelikle yazıya çevrilmiştir. Deney tasarlama kâğıtları ve öz-değerlendirmeleri ile yansıtıcı değerlendirme yazıları doküman olarak toplanmıştır. Görüşmelerden ve yansıtıcı değerlendirme yazılarından elde edilen nitel veriler amaca yönelik olarak betimsel analiz yöntemi kullanılarak analiz edilmiştir. Betimsel analizde elde edilen veriler önceden belirlenen temalara göre özetlenir ve yorumlanır. Betimsel analizde, bireylerin görüşlerini yansıtmak amacıyla doğrudan alıntılara yer verilir (Yıldırım ve Şimşek, 2008). Deney tasarlama kâğıtları ve öz-değerlendirme yazıları betimsel ve içerik analizi yöntemi kullanılarak analiz edilmiştir. İçerik analizinde toplanan verilerin önce kodlanır, sonra ortaya çıkan kodlara göre mantıklı bir biçimde düzenlenir ve buna göre tema ve kategoriler oluşturulur (Yıldırım ve Şimşek, 2008).

\section{Uygulama Süreci}

Araştırma, 2016-2017 eğitim-öğretim yılı güz döneminde Türkiye'de bulunan büyük ölçekli üniversitelerin birinde gerçekleştirilmiştir. Fen bilimleri öğretmenliği lisans programında "fen okuryazarlı̆̆ı" seçmeli dersinde bir dönem boyunca haftada üç saat 38 öğretmen adayı ile argümantasyon destekli araştırma sorgulamaya dayalı uygulamalar yapılmıştır.

İlk hafta dersin tanıtımı ve ön test uygulamaları yapılmıștır. İkinci hafta itibariyle etkinlikler uygulanmaya başlanmıştır. İlk üç etkinlik öğretmen adaylarının araştırma sorgulama ve argümantasyon uygulamalarına adaptasyonu için ısındırma etkinliği niteliğindedir.

Etkinlik 1 Maymun Fıstık Deneyi. Bu etkinlik ile öğretmen adaylarının araştırma ve sorgulama becerilerini ortaya çıkarılması amaçlanmıştır.

Etkinlik 2 Bay Yıldızın Ölümü ve Hayaletli Ev. Bu etkinlik ile öğretmen adaylarına argümantasyon sürecinin genel yapısını oluşturan soru, iddia ve delil kavramları hakkında farkındalık kazanması ve bu kavramları birbirinden ayırt etmesi amaçlanmaktadır.

Etkinlik 3 Sera Etkisi. Bu etkinlik ile öğretmen adaylarına argümantasyon destekli araştırma sorgulama sürecinin genel yapısını oluşturan araştırma sorusu, bağımlı, bağımsız, kontrol değişkeni ve argümanın öğeleri (iddia, delil, gerekçe, destekleyici, niteleyici, çürütücü) hakkında farkındalık kazanması ve bu kavramları birbirinden ayırt etmesi amaçlanmaktadır.

Etkinlik 4'den itibaren argümantasyon destekli araştırma sorgulamaya dayalı öğretim uygulamalarını içeren ana etkinlikler yapılmıştır.

Etkinlik 4 Bir Cismin Suda Yüzme ve Batma Durumlarının Araştırılması. Bu etkinlik ile öğretmen adaylarına bir cismin suda yüzme ve batma durumlarına etki eden faktörlerle ilgili olarak 
argümantasyon destekli araştırma sorgulamaya dayalı farklı etkinlikler tasarlamaları ve uygulamaları amaçlanmıştır.

Etkinlik 5 Cisimlere Etki Eden Yer Çekimi Kuvvetinin ve Hava Direncinin Araştırılması. Bu etkinlik ile öğretmen adaylarına yer çekimi kuvveti ve hava direnci ilgili olarak argümantasyon destekli araştırma sorgulamaya dayalı farklı etkinlikler tasarlamaları ve uygulamaları amaçlanmıştır.

Etkinlik 6 Eğik Düzlemde Hareketin ve Sürtünme Kuvvetinin Araştırılması. Bu etkinlik ile öğretmen adaylarına eğik düzlemde harekete etki eden faktörlerle ve sürtünme kuvvetine etki eden faktörlerle ilgili olarak argümantasyon destekli araştırma sorgulamaya dayalı farklı etkinlikler tasarlamaları ve uygulamaları amaçlanmıştır.

Etkinlik 7 Görünmeyen Kuvvetlerin Araştırılması. Bu etkinlik ile öğretmen adayları görünmeyen kuvvetlerle ilgili olarak argümantasyon destekli araştırma sorgulamaya dayalı farklı etkinlikler tasarlamaları ve uygulamaları amaçlanmıştır.

Etkinlik 8 Maddelerin ve Sıvı Çözeltilerin İletkenlik-Yalıtkanlık Durumlarının Araştırılması. Bu etkinlik ile öğretmen adaylarına elektrik iletkenliği konusunda argümantasyon destekli araştırma sorgulamaya dayalı farklı etkinlikler tasarlamaları ve uygulamaları amaçlanmaktadır.

Etkinlik 9: Lambanın Parlaklığına Etki Eden Faktörlerin Araştırılması. Bu etkinlik ile öğretmen adaylarına lambanın parlaklığına etki eden faktörleler ilgili olarak argümantasyon destekli araştırma sorgulamaya dayalı farklı etkinlikler tasarlamaları ve uygulamaları amaçlanmıştır.

Etkinlik 10 Isı-Sıcaklık İlişkisinin ve Maddeler Arası Isı Geçişinin Araştırılması. Bu etkinlik ile öğretmen adaylarının ısı ve sıcaklık ilişkisini ve maddeler arası ısı geçişi ile ilgili argümantasyon destekli araştırma sorgulamaya dayalı farklı etkinlikler tasarlamaları ve uygulamaları amaçlanmıştır.

Etkinlik 11 Buharlaşma ve Kaynamaya Etki Eden Faktörlerin Araştırılması. Bu etkinlik ile öğretmen adaylarına buharlaşma ve kaynamaya etki eden faktörler ve yüzey gerilimi ilgili olarak argümantasyon destekli araştırma sorgulamaya dayalı farklı etkinlikler tasarlamaları ve uygulamaları amaçlanmıştır.

Etkinlik 12: Erime ve Çözünmeye Etki Eden Faktörlerin Araştırılması. Bu etkinlik ile öğretmen adaylarının erime ve çözünmeye etki eden faktörlerle ilgili olarak argümantasyon destekli araştırma sorgulamaya dayalı farklı etkinlikler tasarlamaları ve uygulamaları amaçlanmıştır.

Öğretmen adaylarının uygulamalar sürecinde öğretmen olduklarında kendi sınıflarında kullanabilecekleri argümantasyon destekli araştırma sorgulama etkinliklerini grup çalışması yaparak tasarlamaları, yürütmeleri, rapor etmeleri, paylaşmaları, tartışmaları ve değerlendirmeleri sağlanmıştır. Örnek etkinlik planı Ek 1'de sunulmuştur.

\section{Geçerlik, Güvenirlik ve Etik}

Uygulama öncesinde Üniversite Etik Komisyonu'ndan gerekli izinler alınmıştır. Uygulama öncesinde öğretmen adaylarına yapılacak araştırma hakkında bilgi verilmiştir. Öğretmen adayları gönüllülük esasına dayalı olarak ön test, son test ve yarı-yapılandırılmış görüşmeye katılmışlardır. Görüşme yapılan öğretmen adaylarını isimleri etik kurallara uygun olarak kodlar kullanılarak rapor edilmiştir. Araştırmanın kapsamında geçerlik ve güvenirlik çalışması yapılmış olan nicel veri toplama aracı izin alarak kullanılmıştır ve ayrıca kullanılmadan önce tekrar güvenirlik çalışması yapılmıştır. Ön test ve son test uygulamaları arasında 13 hafta bulunmaktadır. Araştırmacı, uygulama öncesinde argümantasyon, araştırma sorgulamaya dayalı öğrenme yöntemi ile ilgili dersler ve ulusal ve uluslararası çeşitli eğitimler almış ve uygulamalar yapmıștır. Araştırma kapsamında nicel ve nitel yöntemlerin bir arada kullanılmasıyla yöntem çeşitlenmesi (methodological triangulation) yapılarak araştırmanın iç geçerliliği güçlendirilmiştir. Bulgular kısmında doğrudan alıntılara yer verilerek dış geçerliliği sağlanmıştır (Miles ve Hubberman, 1994; Türnüklü, 2001; Yıldırım ve Şimşek; 2008) 


\section{BULGULAR ve YORUM}

$\mathrm{Bu}$ araştırmada, argümantasyon destekli araştırma sorgulamaya dayalı uygulamaların fen bilimleri öğretmen adaylarının öğretme-öğrenme anlayışlarına ve deney tasarlama becerilerine etkisi araştırılmıştır.

\section{Birinci Alt Probleme Ait Bulgular ve Yorum}

Araştırmanın birinci alt problemine cevap aramak için uygulama öncesi ve sonrasında öğretmeöğrenme anlayışları ölçeği kullanılmıştır. Analizler sonucunda elde edilen uygulama öncesi ve sonrası öğretme-öğrenme anlayış düzeylerinin betimsel istatistik değerleri Tablo 1'de sunulmuştur.

Tablo 1. Uygulama öncesi ve sonrası öğrenme-öğretme anlayıș düzeylerinin betimsel istatistik değerleri

\begin{tabular}{ccccc}
\hline Öğrenme-Öğretme Ölçeği & Ölçüm & $\mathrm{N}$ & $\mathrm{X}$ & $\mathrm{ss}$ \\
\hline Öğrenme-Öğretme Anlayıșı & Ön test & \multirow{2}{*}{30} & 3.51 & .46 \\
& Son test & & 3.61 & .47 \\
Yapılandırmacı Anlayış Boyutu & Ön test & \multirow{2}{*}{30} & 4.67 & .31 \\
& Son test & & 4.72 & .32 \\
& Ön test & \multirow{2}{*}{30} & 2.86 & .72 \\
Geleneksel Anlayıș Boyutu & Son test & & 2.73 & .78 \\
\hline
\end{tabular}

Betimsel istatistik sonuçlarına göre öğretmen adaylarının uygulama öncesinde geleneksel öğrenme-öğretme anlayışından $(X=2.86)$ çok yapılandırmacı anlayışa $(X=4.67)$ sahip olduğu görülmektedir. Uygulama sonrasında yapılandırmacı anlayıș puan ortalamalarının $\operatorname{arttığ}(X=$ 4.72) geleneksel anlayıș puan ortalamalarının ise azaldığ $1(X=2.73)$ sonucuna varılmıștır. $\mathrm{Bu}$ değișimin istatistiksel olarak anlamlı olup olmadığını anlamak için ilișkili ölçümler için Wilcoxon işaretli sıralılar testi uygulanmıştır. Tablo 2'de yapılan Wilcoxon işaretli sıralılar testi sonuçları sunulmuştur.

Tablo 2. Uygulama öncesi ve sonrası öğrenme-öğretme anlayışları puanlarının wilcoxon işaretli sıralar testi sonuçları

\begin{tabular}{clccccc}
\hline Öğrenme-Öğretme Ölçeği & & $\mathrm{n}$ & Sıra Ortalaması & Sıra Toplamı & $\mathrm{Z}$ & $\mathrm{p}$ \\
\hline \multirow{3}{*}{ Öğrenme-Öğretme Anlayışı } & Negatif Sıra & 11 & 16.09 & 177.00 & & \\
& Pozitif Sıra & 19 & 15.16 & 288.00 & $1.14^{*}$ & .253 \\
& Eşit & 0 & - & - & & \\
& Negatif Sıra & 13 & 11.12 & 144.50 & & \\
Yapılandırmacı Anlayış Boyutu & Pozitif Sıra & 13 & 15.88 & 206.50 & $0.79 *$ & .430 \\
& Eşit & 6 & - & - & & \\
& Negatif Sıra & 15 & 13.77 & 206.50 & & \\
Geleneksel Anlayıș Boyutu & Pozitif Sıra & 17 & 18.91 & 321.50 & \multirow{2}{*}{$1.08^{*}$} & .282 \\
& Eșit & 0 & - & - & & \\
\hline
\end{tabular}

Tablo 2'de yer alan analiz sonuçlarına göre, araștırmaya katılan öğretmen adaylarının öğrenme-öğretme anlayış düzeylerinde, geleneksel anlayış düzeylerinde ve yapılandırmacı anlayış düzeylerinde uygulama öncesi ve sonrası puanları arasında istatistiksel olarak anlamlı bir fark olmadığı söylenebilir $(z=1.14 ; p>.05)$.

Araştırmanın birinci alt problemine cevap aramak için nicel verilerin analizin yanı sıra, yarı yapılandırılmış görüşmelerden ve dokümanlardan elde edilen nitel veriler amaca yönelik betimsel analiz yöntemi kullanılarak analiz edilmiştir.

Görüşmeler sırasında öğretmen adayları, yapılan uygulamaların öğretmeyi öğrettiğini, öğretmen olmaya hazırladığını ve fen öğretimi öz-yeterlik inançlarını geliştirdiğini ifade etmişlerdir. Örneğin, görüşme yapılan öğretmen adaylarından ÖA11:"Öğretmen olunca bu tarz 
etkinlikleri öğrencilerime yaptırmayı düşünüyorum. Burada öğrenci odaklı olmanın daha güzel olduğunu keşfettim. Daha iyi öğretebilirim artık." ifadesiyle fen öğretimi öz-yeterlik inancının arttığını ve öğrenci merkezli anlayıșları benimsediğini anlayabiliriz. Görüșme yapılan öğretmen adaylarından ÖA3: "İleride öğretmen olup atandığımızda ilköğretim seviyesindeki öğrencilerimize elimizdeki basit materyallerle o teorik bilgiyi en basit halde nasıl anlaşıllır hale getirip anlatabiliriz. Kafa karıştırmadan daha sağlıklı bir şekilde nasıl öğretmemiz gerektiğini öğrendim. Direk mesela konumuz 'Manyetik alan nedir?' değil de mesela 'Hayatınızda hiç mıknatıs gördünüz mü?', 'Mıknatıs nerelerde var?', 'Hayatımızda nerelerde mıknatıs kullanıyoruz?' şeklinde soru soracağım." şeklindeki ifadesi öğretmeyi öğrendiğini ve öğretme-öğrenme anlayışındaki değişimi ortaya koymaktadır. Başka bir öğretmen adayı ÖA10 ise "...neyin nereden geldiğini çocuklara nasıl sorabilirim. Aslında tam olarak öğrenciye verebilme aşamasını gördüm. Bu soruları nasıl değiştirebilirim de öğrenciye verebilirim bunu yaşadım. Soru sorma şeklim değişti mesela. Artık düz soru sormayacağım yani ben onların araştırmasını, bilmesini isteyeceğim. Merak uyandırmayı ön planda tutacağım. Bunu öğrendim." ifadesi ile bu sürecin öğretmen olmaya hazırladığını ve bu süreçteki öğretme-öğrenme anlayışındaki değişimini anlatmaktadır. Görüşme yapılan öğretmen adaylarından bir diğeri "Bu derste bildiğimiz șeyleri ileride öğrencilerimize nasıl aktarabileceğimizi öğrendik. Farklı bir yöntem öğrendim. Daha önce böyle bir ders ișlememiștim. Genelde hocalarımız anlatıp gidiyorlardı ödev filan veriyorlardı." ifadesi bu öğretmen adayının öğretmeyi öğrendiğini ve geçmişteki öğretme-öğrenme yaşantısı ile yeni öğrendiği öğretmeöğrenme yaklaşımı arasındaki farkın bilincinde olduğunu göstermektedir. Başka bir öğretmen adayı "Bizim geleneksel eğitimde ve ögrretimde öğretmenlerin yaptığı en büyük hatayı görmüş olduk. Çünkü orada hemen öğretmene bir soru sorduğunda ya da işte öğretmen kendi bile soru sorduğunda hemen arkasına kendi cevabı verdiği için biz hiç düşünemedik bize düşünmeyi öğretmediler." ifadesiyle geçmiş öğrenme yaşantısındaki eksiklikleri ve yanlışların olduğunu açıklamaktadır. Görüşme yapılan öğretmen adaylarından başka birisi ise "İlköğretimde geçmiş zamanda biz böyle öğrenmedik teorik bilgi veriyorlardı biz direk alıyorduk sorgulamıyorduk. Direk sıcaklı̆̆ın tanımı şu, ısının tanımı bu. Bunları araştırmayı, sorgulamayı, kökenine inmeye başladık." şeklindeki ifadesinde geçmiş öğretme-öğrenme yaşantısı ile şuan ki öğretme-öğrenme yaşantısını kıyasladığı ve geleneksel anlayıştan yapılandırmacı anlayışa bir geçiş yaşadığı görülmektedir. Bir başka öğretmen adayı ise "Öğrenciye direk cevabı vermemeyi öğrendik" şeklindeki ifadesiyle geleneksel öğretme-öğrenme anlayışından yapılandırmacı öğretmeöğrenme anlayışına geçiş yaşadığını ifade etmiştir. Benzer şekilde ÖA8 kodlu öğretmen adayı da "Bilgiyi öğrenciye direk vermemeyi düşünüyorum artık çünkü direk olarak verirsek öğrencide heyecan kalmaz konuyu öğrendim zaten der geçiştirir. O yüzden sizin yaptığını gibi girişte öğrencilerde merak uyandırmayı, derse ilgilerini çekmeyi istiyorum." ş̧eklinde ifadesinde öğretmeöğrenme anlayışındaki farklılaşmayı açıklamaktadır. Bir diğer öğretmen adayı ÖA4 ise "Ben kendim gelenekselde yetiştim onun farkındayım şuan sürekli öğretmenlerimiz kendileri tamam biliyorlar çok iyiler çok hoşlar ama ben mesela sürekli konuşan parmak kaldıran bir konu üzerinde fikir yürütmeyi seven bir insanım küçükken de öyleydim. Soru sorulduğunda hemen parmak kaldırır açıklardım. Öğretmen hemen doğru filan derdi. Diğer arkadaşlarımıza fırsat vermezdi ya da başkası açıllarsa bana fırsat vermezdi. Bu mesela sıkıcı bir şey çünkü öğretmen kendi sorduğu soruyu bile geri kendisi cevaplayınca hiçbir anlamı kalmıyor. Bütün öğrencilere nasıl söz hakkı vereceğimi öğrendim." ifadesiyle öğretmen olduğunda öğrenci merkezli bir yaklaşımı benimseyeceğini ve demokratik bir sınıf kültürü oluşturmak istediğini açılklamaktadır. Görüşme yapılan öğretmen adaylarından ÖA1: "ileride o konuyu öğrencilerimize öğretirken en azından kafamızda bir taslak olacak. Daha doğru bir șekilde öğrencilere deneylerimizi yaptırabileceğiz. Derste notlar alıyorum. Şu söyle yapılacak, bu böyle yapılacak diye beni ögretmenlik anlamında geliştirdiğini düşünüyorum." ş̧eklindeki ifadesi öğretme-öğrenme süreçlerini tasarlama becerilerinin geliştiğini göstermektedir.

Öğretmen adaylarının yansıtıcı ders değerlendirme yazılarında fen öğretimi öz-yeterlik inançları, öğretmeyi öğrenme becerileri ve öğretme-öğrenme süreci tasarlama becerilerinin geliştiğine dair açıllamalar yer almaktadır. Örneğin, bir öğretmen adayı "Bu derste meslek hayatımda öğrenciyi nasıl aktif hale getireceğimi öğrendim" șeklindeki yansıtması ile öğrenciyi merkeze alarak öğretmeyi öğrendiğini açıklamaktadır. Başka bir öğretmen adayı ise "araştırma 
sorgulamaya dayalı fen eğitimi vermeye çalıştığınız bu derste tam olarak bunu hedeflediği için bu yöntemi tecrübe ederek ögrrendiğimden öğrencilerime de bu yöntemle ders anlatabilirim. Onların kendileri araştırarak sorgulayarak öğrenmelerini sağlayabilirim." şeklindeki yansıtması ile yapılandırmacı öğretme-öğrenme yaklașımını benimsediğini ve bu noktada fen öğretimi özyeterlik inancını artırdığını söyleyebiliriz. Bir başka öğretmen adayı ise "Bu derste 'verimli ders nasıl işlenir?' onu öğrendim. Feni öğrencilere düz anlatım ile anlatmaktansa onlara sorgulamayı, araştırmayı öğreterek bazı kavramları kendilerinin öğrenmesi gerektiğini öğrendim. Öğretmen olduğum zaman fen öğretimi yaklaşımı açısından bu derste öğrendiklerimi kullanacă̆ım" șeklinde yansıtması ile geleneksel anlayıştan ziyade yapılandırmacı anlayışı tercih edeceğini belirtmiştir. Başka bir öğretmen adayı ise "Fen öğretiminde deneyin önemini anladım. Soru sormanın ve sordurmanın çok önemli olduğunu gördüm. Anlamlı ve kalıcı öğretmenin nasıl gerçekleștiğini öğrendim. Fen öğretimi açısından çok büyük katkıları olduğunu söyleyebilirim. Öğretmen olduğumda sınıfımda tam da işlediğimiz gibi dersler ișlemek isterim." șeklindeki yansıtması ile benimsediği ve uygulamak istediği fen öğretimi anlayışını ve öğretmeyi öğrendiğini açıklamıștır. Bir diğer öğretmen adayı ise "Bu derste güdülemenin ve derste soru sormanın ne kadar önemli olduğunu yaşayarak öğrendim. Soyut kavramları deneyler yardımıla nasıl daha somut hale getirerek öğretebileceğimi öğrendim." şeklindeki yansıtması ile deneyimlerinden yola çıkarak fen öğretimi anlayışının şekillendiğini, öğretmeyi öğrendiğini ve fen öğretimi öz-yeterlik inancının geliştiğini ifade etmiştir. Bir diğer öğretmen adayı ise "Bu dersin fen öğretimi açısından bana inanılmaz katkısı oldu. Derse kesinlikle hazırlıklı gitmeliyim. 'Öğrencilerim neler sorabilir?, Onları nasıl güdülerim?, Dikkatlerini nasıl çekerim?, Karşılaştığım sorunları nasıl çözebilirim?’ bu soruların cevabını almış oldum. Meslek hayatımda kullanabileceğim çok güzel bilgiler ve deneyler öğrendim. Aslında burada deneyden çok argümantasyon araştırma sorgulama sürecini öğrenmek ve uygulamaktı. Bu süreci gerçekten çok iyi öğrendim ve bu derste çok iyi uyguladığımı düşünüyorum. Öğretmen olduğumda öğrencilerime ben de bu süreci uygulamayı çok istiyorum." șeklindeki yansıtması ile yapılan uygulamaların sayesinde öğretme-öğrenme süreci tasarlama becerisinin geliştiğini, argümantasyon destekli araştırma sorgulamaya dayalı öğrenme yaklaşımını benimsediğini ve bu süreci yaparak, yaşayarak deneyimlediği için fen öğretim özyeterlik inancını artırdığını belirtmiştir.

\section{İkinci Alt Probleme Ait Bulgular ve Yorum}

Araştırmanın ikinci alt problemine cevap aramak için öğretmen adaylarının uygulama öncesi ve sonrasında hazırlanmış oldukları deney tasarlama ödevlerinden yararlanılmıştır. Uygulama öncesinde ve sonrasında fen bilimleri öğretmen adaylarından sıvıların kaynama noktasının sıvıda çözünmüş katı madde miktarı ile ilişkisini tespit edebilecekleri bir deney tasarlamaları istenmiştir. Elde edilen nitel dokümanlar betimsel analiz ve içerik analiz yöntemleri ile analiz edilmiştir. Uygulama öncesinde 37 öğretmen adayı, uygulama sonrasında ise 25 öğretmen adayını deney tasarlama kâğıdını teslim etmiștir. Öncelikle öğretmen adaylarının deney tasarlama kâğıtları bilimsel süreç becerilerini kazandırma yönünden incelenmiştir. 
Tablo 3. Öğretmen adaylarının uygulama öncesinde ve sonrasında deney tasarlamalarına temel süreç becerilerinin yansımalarına ilișkin frekans ve yüzdeler

\begin{tabular}{ccccc}
\hline \multirow{2}{*}{ Temel Süreç Becerileri } & \multicolumn{3}{c}{ Uygulama Öncesi } & Uygulama Sonrası \\
\cline { 2 - 5 } & 32 & 87 & 25 & 100 \\
\hline Gözlem & $\mathrm{f}$ & - & - & - \\
Sinıflama & - & 5 & 2 & 8 \\
İletişim & 2 & 87 & 25 & 100 \\
Ölçme & 32 & 24 & 10 & 40 \\
Tahmin etme & 9 & 19 & 14 & 56 \\
Yorum yapma & 7 & &
\end{tabular}

Öğretmen adaylarının uygulama öncesinde yapmış oldukları deney tasarlamaları incelendiğinde \% 87'si gözlem ve ölçme becerilerine yer vermiştir. Tahmin etme, yorum yapma, iletişim gibi temel süreç becerilerine ise öğretmen adaylarının büyük çoğunluğunun deney tasarlamalarında yer vermediği belirlenmiștir. Uygulama sonrasında ise deney tasarlama ödevini teslim eden öğretmenlerin tamamının gözlem ve ölçme becerilerine yer verdiği belirlenmiştir. Ayrıca tahmin etme, yorum yapma ve iletişim gibi temel süreç becerilerine yer veren öğretmen adaylarının sayısında artış olduğu sonucuna varılmıştır. Bu bulgu, 14 hafta boyunca yapılan uygulamaların öğretmen adaylarının temel süreç becerilerinin öğretimine yönelik farkındalıklarını geliştirdiği şeklinde yorumlanabilir.

Tablo 4. Öğretmen adaylarının uygulama öncesi ve sonrası deney tasarlamalarına bütünleşik süreç becerilerinin yansımalarına iliş̧kin frekans ve yüzdeler

\begin{tabular}{ccccc}
\hline \multirow{2}{*}{ Bütünleșik Süreç Becerileri } & \multicolumn{2}{c}{ Uygulama Öncesi } & \multicolumn{2}{c}{ Uygulama Sonrası } \\
\cline { 2 - 5 } & $\mathrm{f}$ & $\%$ & $\mathrm{~F}$ & $\%$ \\
\hline Değişkenleri Tanımlama ve Belirleme & 6 & 16 & 14 & 56 \\
Hipotez Kurma & 19 & 51 & 16 & 64 \\
Deney Yapma & 32 & 87 & 25 & 100 \\
Verileri Tablo ile Sunma & 11 & 30 & 15 & 60 \\
Verilerden Grafik Çizme & 2 & 5 & 12 & 48 \\
Veriler Yorumlama & 22 & 60 & 16 & 64 \\
\hline
\end{tabular}

Öğretmen adaylarının uygulama öncesinde ve sonrasında yapmış oldukları deney tasarlamaları bütünleşik süreç becerileri bakımından incelendiğinde \% 16'sinin uygulama öncesinde yaptıkları deney tasarlamalarında araştırmanın bağımlı, bağımsız ve kontrol değişkenlerini açılarken uygulama sonrasında ise \% 56'sinin deney tasarımlarında araştırmalarının değişkenlerini belirlediği görülmektedir. Öğretmen adaylarının \% 2'si uygulama öncesinde yapmış olduğu deney tasarlamalarında verilerden grafik çizme kısmına yer verirken uygulama sonrasında öğretmen adaylarının \% 48'i yapmış olduğu deney tasarlamalarına verilerden grafik çizme kısmını eklediği belirlenmiştir. Benzer şekilde uygulama öncesinde öğretmen adaylarının \% 11'i deney tasarlamaların da verileri tablo ile sunarken uygulama sonrasında \% 60'ının verileri tablo ile sunduğu görülmektedir. Ayrıca hipotez kurma, deney yapma, verileri yorumlama gibi bütünleşik süreç becerilerine yer veren öğretmen adaylarının sayısında artış olduğu sonucuna varılmıştır. Argümantasyon destekli araştırma sorgulamaya dayalı öğretim uygulamalarının öğretmen adaylarının deney tasarımlarına yansımaları bütünleşik süreç becerilerinin öğretimine yönelik farkındalıklarının arttığı yönündedir. 
Ayrıca, öğretmen adaylarının deney tasarlama kâğıtları deney tasarımlarında kullandıkları deney türü yönünden incelenmiştir. Uygulama öncesinde öğretmen adayları daha çok adım adım yönergelerin olduğu kapalı uçlu deney tasarlamalarına yer verdikleri belirlenmiştir. Argümantasyon destekli araștırma sorgulamaya dayalı öğretim uygulamaları öğretmen adaylarını klasik deney anlayışının dışına çıkmalarına ve uygulama sonrası deney tasarımlarında açık uçlu deneylere yönelim gösterdikleri tespit edilmiştir.

Tablo 5 incelendiğinde, uygulama öncesinde öğretmen adaylarının \% 19 kapalı uçlu deney tipinde olduğu gibi teorik bilgiye yer vermişken uygulama sonrasında bu oran \% 8'e düşmüştür. Uygulama öncesinde öğretmen adaylarının \% 19'ü deney tasarlamalarında araştırma sorusuna yer verirken uygulama sonrasında \% 64'ü deney tasarlamalarında araştırma sorusu kısmına yer vermiş̧tir. Uygulama öncesinde öğretmen adaylarının \% 5'i deney tasarlamalarında güvenlik önlemlerine yer verirken uygulama sonrasında ise öğretmen adaylarının \% 28' i deney tasarlamalarında güvenlik önlemleri kısmına yer verdiği belirlenmiştir. Uygulama öncesinde öğretmen adaylarının \% 19' ü deney tasarlamalarında deney verilerini tablo ile sunma kısmına yer verirken uygulama sonrasında öğretmen adaylarının \% 64'ünün deney verilerini tablo ile sunma kısmına yer verdiği tespit edilmiştir. Uygulama öncesinde öğretmen adaylarının \% 5'i deney tasarlamalarında deney verilerinden grafik çizme kısmına yer verdiği, uygulama sonrasında ise öğretmen adaylarının \% 48'inin grafik çizme kısmına yer verdiği görülmektedir. Yapılan argümantasyon destekli araştırma sorgulamaya dayalı öğretim uygulamaları, öğretmen adaylarının uygulama sonrasında deney tasarlamalarına başlangıç düşüncelerim, iddia, delil, hata kaynakları, destekleyiciler, kafama takılanlar, günlük yaşamla ilişkilendirme ve yansımalar gibi kısımlar eklemelerine katkı sağlamıştır.

Tablo 5. Öğretmen adaylarının uygulama öncesi ve sonrası deney tasarlamalarında yer verdikleri kısımlara iliş̧in frekans ve yüzdeler

\begin{tabular}{lcccc}
\hline \multicolumn{1}{c}{ Deney Tasarımlarında Yer alan } & \multicolumn{3}{c}{ Uygulama Öncesi } & \multicolumn{2}{c}{ Uygulama Sonrası } \\
\cline { 2 - 5 } & $\mathrm{f}$ & $\%$ & $\mathrm{f}$ & $\%$ \\
\hline Deneyin Adı & 21 & 57 & 12 & 88 \\
Deneyin Amacı & 11 & 30 & 2 & 72 \\
Teorik Bilgi & 7 & 19 & 16 & 8 \\
Araştırma Sorusu & 7 & 19 & 16 & 64 \\
Hipotez & 17 & 46 & 14 & 64 \\
Değişkenler & 6 & 16 & 24 & 56 \\
Malzeme listesi & 30 & 81 & 25 & 96 \\
Deneyin yapılışı & 31 & 84 & 7 & 100 \\
Güvenlik Önlemleri & 2 & 5 & 16 & 28 \\
Tablo oluşturma & 7 & 19 & 12 & 64 \\
Grafik çizme & 2 & 5 & 22 & 48 \\
Deneyin sonucu & 22 & 60 & 12 & 48 \\
Deneyin yorumu & 4 & 11 & 3 & 12 \\
Değerlendirme & 3 & 8 & 0 & 0 \\
Sayıltılar & 2 & 5 & 1 & 4 \\
Başlangıç düşüncelerim & - & - & 9 & 36 \\
İddia & - & - & 9 & 36 \\
Delil & - & - & 4 & 16 \\
Hata kaynakları & - & - & 2 & 8 \\
Destekleyiciler & - & - & 2 & 12 \\
Kafama takılanlar & - & - & 3 & 4 \\
Günlük yaşamla ilişkilendirme & - & - & 1 & \\
Yansımalar & - & - & & \\
\hline
\end{tabular}


Tablo 6. Öğretmen adaylarının deney tasarlama öz-değerlendirmelerine ilişskin kategori, kod ve frekanslar

\begin{tabular}{|c|c|c|}
\hline Kategori & Kod & f \\
\hline \multirow{2}{*}{ Benzerlik } & Aynı malzemeler & 7 \\
\hline & Kapalı uçlu deney süreci & 3 \\
\hline \multirow{10}{*}{ Farklılık } & Farklı uygulamalar & 12 \\
\hline & Daha kapsamlı ve zengin & 9 \\
\hline & Araştırma sorusu yazma & 6 \\
\hline & Değişkenleri belirleme ve tanımlama & 9 \\
\hline & Gözlemleri tablo ve grafik ile sunma & 7 \\
\hline & Başlangıç düşünceleri & 1 \\
\hline & İddia, delil, destekleyici sunma & 4 \\
\hline & Güvenlik önlemleri alma & 5 \\
\hline & Hata kaynaklarını belirleme & 2 \\
\hline & Yansimalar & 1 \\
\hline \multirow{9}{*}{ Farkındalık } & Beceri odaklı & 11 \\
\hline & Bilimsel araștırma sürecine hizmet eder nitelikte & 6 \\
\hline & Kalıcı ve anlamlı öğrenmeyi destekleyici & 3 \\
\hline & Daha özgün & 3 \\
\hline & Günlük yaşamla ilişkili & 4 \\
\hline & Açlk uçlu deney süreci & 7 \\
\hline & Öğretme yaklaşımındaki değişimi fark etme & 9 \\
\hline & Etkinlik kâğıdı kullanma & 2 \\
\hline & Daha kolay planlama & 3 \\
\hline
\end{tabular}

Öğretmen adaylarından uygulama öncesi ve sonrası yapmış oldukları deney tasarlamalarına ilişkin öz-değerlendirme yapmaları istenmiştir. Öğretmen adaylarının özdeğerlendirme yazıları içerik analizi ile çözümlenerek kategori ve kodlar oluşturulmuştur.

Öğretmen adayları uygulama öncesi ve sonrasında yapmış oldukları deney tasarlama ödevlerinin öz-değerlendirmelerinde benzerlik ve farklılıklara ve bu sürecin onlara katkısına yönelik açılamalara yer vermişlerdir. Öğretmen adaylarından bazılarının görüşleri aşağıda sunulmuştur.

ÖA21: "Dersin başında ve sonunda yaptığım deneyler arasında fark var. Sanırım en belirgin fark, dersin sonunda yaptı̆̆ım deney biraz daha açık uçlu deneye yönelik oldu. Faydasının olacağına inandığım birkaç yer ekledim. Deneyin amacı, deneyde kullanılacak malzemeler bakımından aynı özelliklere sahip. Deneyin yapılıș kısmını değiștirdim. Güvenlik önlemleri, gözlemler, neler öğrendik, günlük yaşam ile ilișkilendirme ve değerlendirme kısımları ekledim. Topladıkları verilerden tablo oluşturmalarını isteyip becerilerine katkıda bulunmak istedim. "

ÖA15: "Her iki deneyde de kullandığım malzemeler birbirine benzerdir. Deney düzeneğimde hemen hemen aynı ama bazı farklılıklar var. Illk olarak araştırma sorusu kısmını ekledim. Değişkenler tablosu yaptım. Çünkü araştıracağımız konuda neleri değiștirip, nelere etki edeceğini, neleri sabit tutmamız gerektiğini daha iyi anlarız. Hipotez ve güvenlik önlemleri kısmı ekledim. Veri tablosundan yola çıkara grafik çizme kısmını ekledim. Çünkü bazen grafikler bize ulaşmamız gereken sonuca daha kolay ulaşmamızı sağlayabilir. Grafikte veriler daha nettir. Neler öğrendik? Kısmın ekledim. Cünkü öğrencilerin bu deney sonucunda neler öğrendiğini ve onlara neler kattığını öğrenmek için. Son olarak günlük yaşamla ilişkilendirme kısmını ekledim. Çünkü fen hayattır, hayatımız fendir. Bu kısım sayesinde öğrenciler günlük hayatla bağdaştırdıkları şeyleri daha çok iyi anlamlandırır ve öğrenirler. Ve daha kalıcı olur."

ÖA3: "Bir önceki deney tasarlama ödevinde deneyimi hazırlarken şuan ki hazırladığım deney tasarlama ödevine nazaran daha fazla zorlanmıștım. Değişkenlerim yoktu bir önceki deney tasarlama ödevimde. Deney adl, deney amacı, hipotez, kullanılan malzemeler ve sonuç kısmından olușmaktaydı bir öncekin ödevim. Șuan da ise buna ek olarak bağımlı değişken, bağımsız değişken, kontrol değişkenlerim mevcuttu. Ve grafik, tablo yapma becerisinden bahsedecek olursam verileri o şekilde anlatma becerim arttı. Bir önceki deney tasarlama ödevinde bu özelliğim yoktu. Bir önceki deney yapılışı kısmında da zorlanıyordum. Acaba nasıl tasarlamalıydım? Hangi malzemeleri kullanmalıydım? Gibi bir takım soruluklar yaşıyordum ama şuan ki yaptığım tasarlamada bu gibi sorulara takılmadan kolayca olușturabildim. Bir öncekinde anlașılır anlatmamıș olabilirdim deney așamalarını. Suan kinde ise daha anlaşılır, yalın ve basit șekilde anlattım. Kısacası öncesi ve sonrası arasında fazlaca farkları görebiliyorum. Kendimde ilerlemeyi daha iyi görüyorum. Bu da tabi ki den okuryazarlığı dersindeki deney tasarlama yapmamız sayesinde kazandığım bir şey oldu." 
ÖA10: "Arada çok farkın olduğunu görebiliyorum. O farklara bakacak olursak; dönemin basında deney tasarlama basamaklarını detaylı bir șekilde olușturamıorduk. Deney düzeneğinde iki veriye yer vermiștim ama șimdi oluşturduğum deney tasarlamada üç veriye ver verdim ki sonuçları daha iyi gözlemleyebilelim. Çünkü bazı deneylerde iki veri bizi yanıltabilir üç veri sonuçlarda daha doğru olur. Deney tasarlama basamaklarını daha ayrıntılı, daha açıklayıcı oluşturabildiğimi görebiliyorum. Bağımlı değișken, bağımsız değișken ve kontrol değiş̧kenini daha doğru oluşturabiliyorum. Deney tasarlama adımlarını yani yapılışını daha açıklayıcı bir şekilde yazabiliyorum. Deneydeki hata kaynaklarını daha rahat oluşturabiliyorum. Deney tasarlama ödevinde ilk hafta ve son haftaki değişme net bir şekilde ortada diye düşünüyorum. Bu gelişmeyi sağlayan şeyi düşündüğümüzde ise her hafta etkinliklerimizde deney düzeneği tasarlamamız ardından deneyimizle ilgili olan her şeyi rapora not etmemizin büyük etkisi olduğunu düșünüyorum."

ÖA17: "İlk deneyimde deney malzemelerini ve nasıl yapıldığını ayrıntılı bir șekilde yazmıştım deneyin adına ve hipotezine yer vermiștim. Deneyin içeriği aynı kaldı. Yalnızca ilk deneyimi tasarlarken argümantasyon sürecini bilmiyordum. Bu yüzden de klasik deney sürecini göz önünde bulundurarak deneyin adl, amacl, yapılışı ve sonucu kısımlarına yer vermiştim. Şuan tasarladığım deneyin argümantaston sürecini yansıttığını düşünüyorum. Argümantasyon sürecinde hipotez, araştırma sorusu, iddia, delil, deney ölçümleri, sonuçlar ve deney tasarlama kısımlarına yer vermiştik. Bu nedenle ilk deneyime ek olarak araștırma sorusu, iddia, delil, düşüncelerim değiști ve değișmedi kısımlarını ekledim. “

ÖA2: "Bu deneyi dersin bașında da tasarlamıștım. Șuan o yaptığım tasarım aklıma geliyor da ne kadar amatörce olduğunu düşünüyorum. Bağımlı, bağımsız ve kontrol değişkenlerinin ne olduğunu bilmiyordum. Bağımlı ve bağımsız değişkeni öğrenmeye çalıştıysam da bir türlü anlamlandıramıyordum. Buna bağlı olarak da yaptığım deney tasarlamalarında hatalar yapabiliyordum. Dersin sonunda isse, bağımlı ve bağımsız değişkeni çok iyi öğrendim. Şimdi sorunlara daha bilimsel yaklaşabiliyorum. Deneyin yapımında 1-2 deneme ile en geçerli sonuca varılamayacağını öğrendim. Bu nedenle bu tasarıma deneme așamasını artırarak ișe bașladım. (3 farklı tuz miktarına sahip sıvıyı gözlemlemek için). İlk tasarımımda ise 2 kabın ilkine su ikincisine ise su ve tuz koyduğumu hatırlıyorum. Ne kadar da eksik olduğunu şuan görebiliyorum. Benzerlik açısından kullanılan temel malzemeler aynı ama uygulama açısından farklı. Bunları görebilmemin bana çok büyük avantaj sağladığını ve bu dersin bana çok şey kattığının farkında olmanın mutluluğu içerisindeyim. "

Öğretmen adaylarının deney tasarlama kâğıtlarından elde edilen veriler ve özdeğerlendirmeleri göz önünde bulundurulduğunda sonuç olarak yapılan argümantasyon destekli araștırma sorgulamaya dayalı öğretim uygulamalarının öğretmen adaylarının bilimsel süreç becerilerinin öğretimine yönelik farkındalıklarını arttırdığı ve öğretme-öğrenme anlayışlarında araştırma sorgulamaya yönelik bir değişim oluşturduğu belirlenmiştir.

\section{TARTIŞMA ve SONUÇ}

$\mathrm{Bu}$ araştırmada, argümantasyon destekli araştırma sorgulamaya dayalı uygulamaların öğretmen adaylarının öğretim yeterliklerinin geliştirilmesindeki etkisi araștırılmıştır.

Araştırmanın ilk alt problemi kapsamında elde edilen nicel analiz sonuçları argümantasyon destekli araştırma sorgulamaya dayalı öğretim uygulamalarının öğretmen adaylarının öğretme-öğrenme anlayış düzeylerinde istatistiksel olarak anlamlı bir farklılık oluşturmadığını $[\mathrm{z}=1.14 ; \mathrm{p}>.05]$ göstermesine rağmen nitel bulgular yapılan uygulamaların öğretmen adaylarının öğretme-öğrenme anlayışlarının gelişmesine katkı sağladığını göstermektedir. Yapılan uygulamaların istatistiksel olarak anlamlı bir değișime neden olmamasının sebepleri düşünüldügünde; öğretmen adaylarının uygulama öncesinde de yapılandırmacı anlayışı $(X=4.67)$ desteklemeleri olabilir veya öğretmen adayları her ne kadar yapılandırmacı anlayışa sahip olduklarını düşünseler de Bıkmaz'ın (2017) belirttiği gibi kimi zaman geleneksel anlayışa meyil etmeye devam ediyor olabileceğidir. İstatistiksel olarak anlamlı bir değişimin olmaması olumsuz olarak değerlendirilmemektedir. Bu doğrultuda nicel ölçme yöntemlerine nazaran nitel ölçme yöntemlerinin öğretmen adaylarının sahip oldukları öğretmeöğrenme anlayışlarının daha gerçekçi ve açık bir şekilde ortaya koyabileceği düşüncesiyle nitel veri toplama araçlarıyla toplanan veriler amaca yönelik betimsel analiz yöntemi kullanılarak analiz edilmiştir. Burada yöntem çeșitlemesi (Methodogical Triangulation) yapılarak aynı araştırma sorusu için nicel ile nitel yöntemlerle elde edilen bulguların karşılaştırılması sağlanarak sonuçların güvenirliği ve daha zengin ayrıntılı hale getirilmesi sağlanmıştır. Görüșmeler sırasında öğretmen adayları, yapılan uygulamaların öğretme-öğrenme süreçlerini tasarlama becerilerini geliștirdiğini, öğretmeyi öğrettiğini, öğretmen olmaya hazırladığını ve fen öğretimi öz-yeterlik inançlarını geliştirdiğini ve öğretme-öğretme anlayışlarındaki değişimi önceki öğrenme yaşantılarından örnekler vererek karşılaştırmışlardır. Yapılan uygulamalar ile 
öğretmen adaylarının argümantasyon destekli araştırma sorgulamaya dayalı öğrenme ortamını birebir yaparak yaşayarak öğrenmesi ve öğretmen oldukları zaman öğrencilerine bu tarz etkinlikler yaptırmak için kendini yeterli hissetmesi amaçlanmıştır. Çünkü öğretmen adaylarının feni nasıl öğreteceklerini öğrenmeleri ileride öğretmen oldukları zaman nasıl öğretmen olacaklarını etkileyeceği yani bir başka deyişle benimseyecekleri öğretme-öğrenme anlayışını belirleyeceği düşünülmektedir. Görüşme yapılan öğretmen adaylarının neredeyse hepsi ilköğretim ve ortaöğretim yıllarına ait öğrenme yaşantılarına eleştirel bir bakış açısıyla o yıllardaki öğretmen-öğrenci rollerine ve öğrenme ortamına değinmişlerdir. Öğretmen adaylarından biri "Öğrencilerime bir dersi nasıl öğretebileceğim hakkında bilgi sahibi oldum ve uygulamalı olarak gördüm" şeklindeki yansıtması ile öğretmen adaylarına bir öğrenme yaklaşımını öğretirken teorik olarak sunmaktan ziyade uygulamalı olarak o öğrenme sürecinin içinde bulunmasının daha etkili olduğunu desteklemektedir. Erduran, Ardaç ve Güzel (2006) öğretmen adaylarının argümantasyon süreçlerine katılmaları onların pedagojileri üzerinde olumlu etkileri olduğunu belirlemiştir. Öğretmen adaylarının öğrenci merkezli öğretmeöğrenme anlayışını benimsemeleri ve bunu yaşantılarına yansıtmaları için öğrenci merkezli öğrenme ortamında yaşayarak bu süreci deneyimlemelerinin oldukça kritik olduğu görülmektedir. Öğretmen adayları yansıtıcı ders değerlendirme yazılarında öğretmen olduklarında argümantasyon destekli araștırma sorgulamaya dayalı öğrenme yaklaşımını kullanacaklarına dair açılklamalara yer vermişlerdir. Öğretmen adayları kendi öğrenme yaşantılarından yola çıkarak öğretme-öğrenme anlayışındaki değişim ve gelişime dair yansıtmalara yer vermişlerdir. Ayrıca, fen öğretimi öz-yeterlik inançları, öğretmeyi öğrenme becerileri ve öğretme-öğrenme süreci tasarlama becerilerinin geliştiğine dair açılamalara da rastlanmıștır. Alan yazında yer alan öz-yeterlik seviyesi yüksek olan öğretmenlerin daha fazla öğrenci merkezli anlayışı benimsediğine dair bulgu bu düşüncemizi destekler niteliktedir (Baş, 2014; Ocak, Ocak ve Kalender, 2017). Sonuç olarak her ne kadar elde edilen nicel bulgular öğretmen adaylarının öğretme-öğrenme anlayışlarında anlamlı bir farklılık olmadığını ortaya koysa da elde edilen betimleyici nitel bulgular öğretmen adaylarının argümantasyon destekli araştırma sorgulamaya dayalı öğretim uygulamalarını deneyimlemeleri; fen öğretimi tutum ve öz-yeterliklerine olumlu yönde katkı sağladığını, öğretme-öğrenme süreci tasarlama becerilerini geliştirdiğini, benimsedikleri öğretme-öğrenme anlayışlarında bir takım değişim ve farkındalığa neden olduğunu, öğrenci merkezli anlayışa doğru bir geçiş yaşadıklarını ortaya koymaktadır. Benzer ve Kaygısız (2017) tarafında yapılan çalışmada da öğretmen adaylarının fen deneylerini sadece geleneksel yaklaşımla yapılabileceği algılarının değiştiğini ve öğretmen olduklarında yapılandırmacı yaklaşımı kullanmak istediklerini tespit etmiştir

Araştırmanın ikinci alt problemi kapsamında incelenen öğretmen adaylarının uygulama öncesi ve sonrası deney tasarlama çalışmalarına ait bulgularda öğretmen adaylarının öğretmeöğrenme anlayışlarındaki değişimi açık bir şekilde ortaya koymaktadır. Uygulama öncesinde öğretmen adayları daha çok adım adım yönergeleri olan kapalı uçlu deney tasarımlarına yer verirken yapılan uygulamalar sonrasında ise argümantasyona, araştırma sorgulamaya dayalı açık uçlu deney tasarlamalarına yönelim gösterdikleri belirlenmiştir. Öğretmen adaylarının deney tasarlama çalışmaları bilimsel süreç becerileri kazandırma yönünden incelediğinde öğretmen adaylarının çoğu uygulama öncesi deney tasarımlarında temel süreç becerilerinden gözlem ve ölçme becerisini geliștirmeye yönelik bölümlere yer verdiği, uygulama sonrasında ise deney tasarımlarına tahmin etme, yorum yapma ve iletişim becerisini geliştirici bölümler ekledikleri belirlenmiştir. Aynı zamanda, öğretmen adaylarının çoğu uygulama öncesi deney tasarımlarında bütünleşik süreç becerilerinden deney yapma, hipotez kurma ve verileri yorumlama becerilerini geliștirmeye yönelik bölümlere yer verdiği, uygulama sonrasında ise değişkenleri belirleme, verileri tablo ile sunma, verilerden grafik çizme becerilerini geliştirici bölümler ekledikleri tespit edilmiştir. Sonuç olarak öğretmen adaylarının uygulama sonundaki deney tasarımları öğrencilerin bilimsel süreç becerilerinin gelişimine hizmet edecek niteliklere sahip olduğu söylenebilir. Öğretmen adayları uygulama öncesi ve sonrasında yapmıș oldukları deney tasarlama çalışmalarında farklılık olduğunu kendileri de ifade etmiş̧tir. Dersin sonunda yaptıkları deney tasarımlarının daha açık uçlu deneye yönelik olduğunu ve ekledikleri bölümlerin öğrencilerin öğrenmelerine ve becerilerini geliştirmeye katkı sağlayacağını 
belirtmişlerdir. Ayrıca, uygulama öncesinde deney tasarlarken yaşadıkları zorlukları uygulama sonrasında deney tasarlarken yaşamadıklarını, her hafta kendi deneylerini tasarlama, yürütme ve rapor etmelerinin kendilerini geliștirdiğini ve daha deneyimli hissettiklerini ifade etmişlerdir. Birçok araştırmada öğretmen adaylarının hizmet öncesi eğitim sürecinde deney tasarlama ve yürütme konusunda yeterli eğitim alamamalarından dolayı zorlandıkları ve özgüven eksikliği yaşadıkları belirlenmiştir (Aydoğdu, 1999; Çoştu vd., 2005; Uluçınar, Cansaran ve Karaca, 2004). Benzer şekilde Benzer, Kaygısız ve Uçar (2017) yaptığı çalışmasında öğretmen adaylarının deney tasarlama sürecinde başında tablo ve grafik çiziminde zorluk yaşadığını, zamanla nasıl daha iyi deney tasarlayabileceklerini öğrendiklerini ve öğretmen olduklarında uygulamak istediklerini belirlemiştir. Hizmet öncesi öğretmen eğitiminde, öğretmen adaylarının bizzat kendi deneylerini tasarlama ve yürütmelerinin ne kadar önemli olduğu görülmektedir. $\mathrm{Bu}$ araştırmanın bulgularına paralel olarak Kocakülah ve Savaş (2011) deney tasarlama ve uygulama süreci sonunda öğretmen adaylarının mesleki deneyim kazandıklarını, özgüvenlerinin arttığını belirlemiştir. Ayrıca, Çoban ve Sanalan (2012) tarafında yapılan araştırmada özgün deney tasarım sürecinin öğretmen adaylarının öz-yeterlik algısını geliştirdiği vurgulanmıştır. Hizmet öncesi öğretmen eğitiminde, öğretmen adaylarının bizzat kendi deneylerini tasarlama ve yürütmelerinin ne kadar önemli olduğu görülmektedir. 14 hafta boyunca yapılan argümantasyon destekli araştırma sorgulamaya dayalı öğretim uygulamaların öğretmen adaylarının deney tasarlamalarına yansımasında bilimsel süreç becerilerinin öğretimine yönelik farkındalıklarının oluştuğunu ve deney tasarlamalarında açık uçlu araştırma sorgulamaya yönelik bir değişim yaşadıklarını göstermektedir. Uygulamalar, öğretmen adaylarının bir deneyin ne olduğundan çok nasıl yapıldığının öneminin farkına varmalarına neden olmuştur.

Sonuç olarak yapılan uygulamaların öğretmen adaylarının argümantasyon destekli araştırma sorgulamaya dayalı öğretim yeterliklerinin geliştirilmesine katkı sağladığı söylenebilir. Öğretmen adaylarının öğrenci merkezli öğretme-öğrenme anlayışını benimsemeleri ve bunu yaşantılarına yansıtmaları için öğrenci merkezli öğrenme ortamında yaşayarak bu süreci deneyimlemelerinin oldukça kritik olduğu görülmektedir. Bu bağlamda öğretmen eğitim programlarında daha çok uygulamaya yönelik eğitimlere yer verilmesi sağlanarak öğretmen adaylarının ve öğretmenlerin güncel öğretim yaklaşımlarını benimsemeleri sağlanabilir. Böylelikle, öğrencilerin çağın gereklerine uygun bir biçimde yetiştirilmesi olanaklı hale getirilebilir.

\section{KAYNAKÇA}

Akıncı, B. Uzun, N. \& Kışoğlu, M. (2015). Fen bilimleri öğretmenlerinin meslekte karşılaştıkları problemler ve fen öğretiminde yaşadıkları zorluklar. International Journal of Human Sciences, 12(1), 11891215.

American Association for the Advancement of Science [AAAS]. (1990). Science for all Americans. New York: Oxford University Press.

American Association for the Advancement of Science [AAAS]. (1993). Benchmarks for science literacy. New York: Oxford University Press.

Aydın, S. \& Çakıroğlu, J. (2010). İlköğretim fen ve teknoloji dersi öğretim programına ilişkin öğretmen görüşleri: Ankara örneği. İlköğretim Online, 9(1), 301-315.

Aydoğdu, C. (1999). Kimya laboratuvar uygulamalarında karşılaşılan güçlüklerin saptanması. Hacettepe Üniversitesi Ĕgitim Fakültesi Dergisi, 15, 30-35.

Aypay, A. (2011). Öğretme ve öğrenme anlayışları ölçeğinin Türkçe uyarlaması ve epistemolojik inançlar ile öğretme ve öğrenme anlayışları arasındaki ilişki. Kuram ve Uygulamada Eğitim Bilimleri, 11(1), 7-29.

Barrow, L. H. (2006). A brief history of inquiry: From Dewey to standards. Journal of Science Teacher Education, 17(3), 265-278.

Baş, G. (2014). İlköğretim öğretmenlerinin öğretme-öğrenme anlayışlarının bazı değişkenler açısından değerlendirilmesi. Dicle Üniversitesi Ziya Gökalp Eğitim Fakültesi Dergisi, 22, 18-30. 
Bayram, Z. (2015). Öğretmen adaylarının rehberli sorgulamaya dayalı fen etkinlikleri tasarlarken karşılaştıkları zorlukların incelenmesi. Hacettepe Üniversitesi Eğitim Fakültesi Dergisi, 30(2), 1529.

Benzer, E., \& Kaygısız, G. M. (2017). Öğretmen adaylarının ortaokul fen deneylerini yapılandırmacı yaklaşıma dayalı tasarlama düzeylerinin ve tasarım hakkındaki görüşlerinin incelenmesi. Gaziantep University Journal of Social Sciences, 2(16). 386-409.

Benzer, E., Kaygısız, G. M., \& Uçar, M. (2017). Fen bilgisi öğretmen adaylarının bilimsel süreç becerilerine dayalı deney tasarımlarının değerlendirilmesi. Sakarya University Journal of Education, 7(3), 467483.

Bıkmaz, F. (2017). Öğretmen Adaylarının öğretme-öğrenme anlayışları ve bilimsel epistemolojik inançlarının araştırılması: Boylamsal bir çalışma. Eğitim ve Bilim, 42(189).

Bybee, R. W. (1997). Achieving scientific literacy: from purposes to practices. portsmouth, NH: Heineman.

Capps, D. K., Crawford, B. A., \& Epstein, J. A. (2010, March). Teachers translating inquiry-based curriculum to the classroom following a professional development: A pilot study. In The National Association of Research in Science Teaching Annual Conference, Philadelphia, PA.

Chan, K. W. \& Elliot, R. G. (2004). Relational analysis of personal epistemology and conceptions about teaching and learning. Teaching and Teacher Education, 20, 817- 831.

Creswell, J. W. (2009). Research design: Qualitative, quantitative, and mixed methods approaches (3rd ed.). Thousand Oaks, CA: Sage Publications.

Çoban, A. \& Sanalan, V. (2012). Fen bilgisi öğretimi dersinde özgün deney tasarım sürecinin öğretmen adayının öz yeterlilik algısına etkisi. Erzincan Üniversitesi Eğitim Fakültesi Dergisi, 4(2), 1-10.

Çoştu, B., Ayas, A., Çalık, M., Ünal, S., \& Karataş, F. Ö. (2005). Fen öğretmen adaylarının çözelti hazırlama ve laboratuvar malzemelerini kullanma yeterliliklerinin belirlenmesi. Hacettepe Eğitim Fakültesi Dergisi,28, 65-72.

DeBoer, G. E. (2000). Scientific literacy: another look at its historical and contemporary meanings and its relationship to science education reform. Journal of Research in Science Teaching, 37(6), 582-601.

Demirel, Ö. (2005). Eğitimde program geliştirme: Kuramdan uygulamaya. Ankara: PegemA Yayıncılık.

Driver, R., Newton, P. \& Osborne J. (2000). Establishing the norms of scientific argumentation in classrooms. Science Education, 84, 287-312.

Duschl, R. A., Schweingruber, H. A., \& Shouse, A. W. (2007). Taking science to school: Learning and teaching Science in grades $K$-8: National Academies Press.

Erduran, S., \& Jiménez-Aleixandre, M. P. (2007). Argumentation in science education: Recent developments and future directions. Dordrech: Springer

Erduran, S., Ardaç, D. \& Güzel, B. (2006). Learning to teach argumentation: Case studies of pre-service secondary science teachers. Eurasia Journal of Mathematics, Science and Technology Education, 2(2), 1-14

Fraenkel, J. R., Wallen, N. E., \& Hyun, H. H. (2012). How to design and evaluate research in education (8th ed.). New York Mc Graw HIll.

Geçer, A., \& Özel, R. (2012). İlköğretim fen ve teknoloji dersi öğretmenlerinin öğrenme-öğretme sürecinde yaşadıkları sorunlar. Kuram ve Uygulamada Eğitim Bilimleri, 12(3), 1-26.

Gücüm, B. \& Kaptan, F. (1992). Dünden bugüne ilköğretim fen bilgisi programları ve öğretim, Hacettepe Üniversitesi Ĕgitim Fakültesi Dergisi, 8, 249-258.

Kaya, H. \& Böyük, U. (2011). Fen bilimleri öğretmenlerinin laboratuvar çalışmalarına yönelik yeterlikleri. Erciyes Üniversitesi Fen Bilimleri Enstitüsü Dergisi, 27(1), 126-134.

Koballa, T. R., Glynn, S. M., Leslie, U., \& Coleman, D. (2005). Conceptions of teaching science held by novice teachers in an alternative certification program. Journal of Science Teacher Education, 16, 287308.

Kocakülah, A., \& Savaș, E. (2011). Fen bilgisi öğretmen adaylarının deney tasarlama ve uygulama sürecine ilişkin görüşleri. Ondokuz Mayıs Üniversitesi Eğitim Fakültesi Dergisi, 30(1), 1-28.

Küçüköner, Y. (2011). 2005 Fen ve teknoloji dersi öğretim programının uygulanmasında karşılaşılan sorunlar ve öğretmen gözüyle çözüm önerileri. Erzincan Eğitim Fakültesi Dergisi, 13(2), 11-37.

Matthews, M. R. (1994). Science teaching: The role of history and philosophy of science. Psychology Press.

Merriam, S.B. (2009). Qualitative research: A guide to design and implementation. San Francisco: JosseyBass.

Miles, M. B., \& Huberman, A. M. (1994). Qualitative data analysis: An expanded sourcebook. (2nd ed.) Sage.

Milli Eğitim Bakanlı̆̆ [MEB] (2000). İlköğretim okulu fen bilgisi dersi öğretim programı. Ankara: Milli Eğitim Basımevi.

Milli Eğitim Bakanlığı [MEB] (2005). İlköğretim fen ve teknoloji (6, 7. ve 8. Sınıflar) öğretim programı. Ankara: Talim ve Terbiye Kurulu Başkanlığı. 
Milli Eğitim Bakanlı̆̆ı [MEB] (2013). İlköğretim kurumları (ilkokullar ve ortaokullar) fen bilimleri dersi (3, 4, 5, 6, 7 ve 8. Sınıflar) öğretim programı. Ankara: Talim ve Terbiye Kurulu Başkanlığı.

Milli Eğitim Bakanlığı [MEB] (2018). Fen bilimleri dersi öğretim programı. (ilkokul ve Ortaokullar 3, 4, 5, 6, 7 ve 8). Ankara: Talim ve Terbiye Kurulu Başkanlığı.

National Research Council [NRC] (1996). National science education standards. USA: National Academy Press, Washington, DC.

National Research Council [NRC] (2000). Inquiry and the national science education standards: A guide for teaching and learning. National Academies Press.

Newton, P., Driver, R., \& Osborne, J. (1999). The place of argumentation in the pedagogy of school science. International Journal of Science Education, 21, 553-576.

Ocak, G., Ocak, İ., \& Kalender, D. (2017). Öğretmenlerin öz-yeterlik algıları ile öğretme-öğrenme anlayışları arasındaki ilişkinin incelenmesi. Kastamonu Üniversitesi Eğitim Fakültesi Dergisi, 25(5), 18511864.

Smith, D. C., \& Anderson, C. W. (1999). Appropriating scientific practices and discourses with future elementary teachers. Journal of Research in Science Teaching, 36(7), 755-776.

Şimşek, H. Hırça, N., \& Çoskun, S. (2012). İlköğretim fen ve teknoloji öğretmenlerinin öğretim yöntem ve tekniklerini tercih ve uygulama düzeyleri: Şanlıurfa ili örneği. Mustafa Kemal Üniversitesi Sosyal Bilimler Enstitüsü Dergisi, 9(18), 249-268.

Uluçınar, Ş., Cansaran, A. \& Karaca, A.(2004). Fen bilimleri laboratuvar uygulamalarının değerlendirilmesi. Türk Ĕ̆itim Bilimleri Dergisi, 2(4), 465-475.

Türnüklü, A. (2001). Eğitim bilim alanında aynı araştırma sorusunu yanıtlamak için farklı araştırma tekniklerinin birlikte kullanılması. Eğitim ve Bilim, 26(120), 8-13

Yıldırım, A. \& Șimșek, H. (2008). Sosyal bilimlerde nitel araștırma yöntemleri. Ankara: Seçkin Yayınları.

Yoon, H. G., Joung, Y. J., \& Kim, M. (2012). The challenges of science inquiry teaching for pre-service teachers in elementary classrooms: Difficulties on and under the scene. Research in Science Education, 42(3), 589-608.

EK 1: Etkinlik 12 Erime ve Çözünmeye Etki Eden Faktörlerin Araștırılması

\begin{tabular}{|c|c|}
\hline Etkinliğin Amacı & $\begin{array}{l}\text { Bu etkinlik ile öğretmen adaylarının erime ve çözünmeye etki eden faktörlerle ilgili } \\
\text { olarak argümantasyon destekli araştırma sorgulamaya dayalı farklı etkinlikler } \\
\text { tasarlamaları ve uygulamaları amaçlanmıștır. }\end{array}$ \\
\hline Yöntem ve Teknikler & Argümantasyon, Araștırma sorgulamaya Dayalı Öğretim \\
\hline Etkinliğin Türü & Sınıf içi etkinlik \\
\hline Etkinliğin Süresi & $40^{\prime}+40^{\prime}+40^{\prime}$ \\
\hline Etkinlik No & 12 \\
\hline Sinıf ve Konu Alanı & Fen Öğretmen Adayları/Öğrenciler \\
\hline
\end{tabular}

\section{İlköğretim Fen Öğretimi Programına Yönelik Kazanımlar:}

4.3.4. Maddenin Isı Etkisiyle Değişimi

4.3.4.1. Maddelerin ısınıp-soğumasına yönelik deneyler tasarlar ve yapar.

4.3.4.2. Maddelerin isl etkisiyle hal değiștirebileceğine yönelik deney yapar ve sonuçları yorumlar. Hâl değişimlerinden sadece erime ve donmaya değinilir.

5.3.2. Maddenin Ayırt Edici Özellikleri

5.3.2.1. Saf maddelerin ayırt edici özelliklerinden erime, donma ve kaynama noktalarını, yaptığı deneyler sonucunda belirler.

7.3.3. Karışımlar

7.3.3.2. Homojen karışımların çözelti olarak da ifade edilebileceğini belirtir.

7.3.3.3. Günlük yaşamda karşılaștığı çözücü ve çözünenleri kullanarak çözelti hazırlar.

7.3.3.4. Çözünme hızına etki eden faktörleri deney yaparak belirler. Temas yüzeyi, karıștırma ve sıcaklık faktörlerine değinilir.

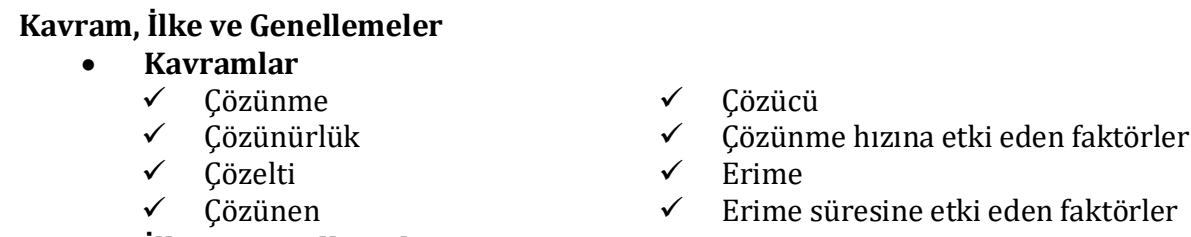


Sıvının sıcaklığının değişmesi hem çözünürlüğe hem de çözünme hızına etki eder.

$\checkmark \quad$ Sıcaklığın artması katı ve sıvıların çözünürlügünü artırır.

$\checkmark$ Sıcaklığın artması çözünme hızını artırır.

$\checkmark$ Gazların çözünürlüğü sıcaklık ile ters orantılıdır.

$\checkmark \quad$ Katıların suda çözünmesi endotermiktir. Sıcaklık arttıkça çözünürlük artar.

$\checkmark \quad$ Basınç gazların çözünürlüğünü değiştirir.

$\checkmark \quad$ Çözünen maddenin tanecik boyutu çözünme hızına etki eder, çözünürlüğü değiștirmez.

\section{Kazandırılacak Beceriler}

\section{- Bilimsel Araştırma Becerileri}

Temel Süreç Becerileri

$\checkmark$ Gözlem yapma

$\checkmark$ İletişim Kurma

$\checkmark$ Tahmin Etme

$\checkmark$ Yorum Yapma

\section{Bütünleştirilmiş Süreç Becerileri}

$\checkmark$ Değișkenleri Tanımlama ve Kontrol Etme

$\checkmark$ Hipotez Kurma ve Test Etme

$\checkmark$ Verileri Kaydetme ve Yorumlama

$\checkmark$ Deney Yapma

$\checkmark$ Model Oluşturma

- Argüman Kurma Becerileri

$\checkmark$ İddia

$\checkmark \quad$ Delil

$\checkmark$ Gerekçe

$\checkmark$ Destekleyici

$\checkmark \quad$ Çürütücü

- Bilimin Doğası Anlama

$\checkmark \quad$ Bilimsel bilgi deneysel verilere dayalıdır.

$\checkmark$ Gözlem ve çıkarım birbirinden farklıdır.

$\checkmark \quad$ Hayal gücü ve yaratıcılık

- Yaşam Becerileri
$\checkmark \quad$ Eleștirel düșünme
$\checkmark$ Üstbiliş farkındalık
$\checkmark$ Sorgulayıcı düșünme
$\checkmark$ Bilimsel akıl yürütme
$\checkmark$ Bilimsel iletişim
$\checkmark$ Yansıtıcı düșünme
$\checkmark$ Yaratıcı düșünme
$\checkmark$ İş birlikli çalışma

\section{Așama: Büyük Grup Tartışması}

Bu aşamada öğrencilerin yaşadığı çevreyi anlayabilmesi amaçlanmaktadır. Öğretmen öğrencilerde merak duygusunu oluşturmak için öğrencilere tek bir doğru cevabı olan sorulardan ziyade düşündürücü açık uçlu sorular sorarak konu hakkında neleri doğru bildiğini, neleri yanlış bildiğini veya neleri öğrenmek istediğini fark etmelerini sağlar.

1. Behere bir miktar su konulur içerisine şeker atılıp karıştırılır. Şeker nereye gitti? Şekere ne oldu?

2. Elimde $100 \mathrm{ml}$ su ve 10 gram şeker var. Suyun içerisine şekeri attığım zaman kütlesi ve hacmi hakkında ne düşünürsünüz? Peki, niçin kütlesi artarken, hacmi artmadı?

3. Kahve yaparken sıcak su kullanırız ve karıştırırız. Soğuk su kullandığımızda ne olmasını bekleriz? Sıcaklık ne fark yaratır? Maddenin tanecikli yapısı açısından bu durumu nasıl açıklayabilirsiniz?

4. Aynı çözücüde bütün maddelerin çözünmeleri aynı mıdır?

5. Asitli içeceklerin üzerinde soğuk içiniz yazmasınız sizce sebebi nedir?

6. Çözünürlüğe etki eden faktörler nelerdir?

7. Çözünme nedir? Çözelti nedir? Çözücü ve çözünen nedir? Aşırı doymuş, doymuş ve doymamış çözeltiler ne demektir?

8. Derişimin artması çözünme hızına nasıl etki eder?

9. Çözünme hızına etki eden faktörler nelerdir?

10. Bir buz parçasını su içerisine attığımızda ne olur?

11. Erime nedir? Buz erirken yapısı nasıl değișir? Bu değiş̧im kimyasal mı yoksa fiziksel bir değişim midir?

12. Buz eridiğinde kütlesinde yani tanecik sayısında bir artış olur mu?

13. Buz eridiğinde hacmi nasıl değişir? Azalmasının sebebi nedir?

14. Kıș aylarında kar yağdıktan sonra yollara tuzlu çakıl taşlarının atılmasının sebebi nedir? Tuz yerine șeker kullanılsaydı ne olurdu?

15. Buz parçalarının şekli erime süresini etkiler mi? Peki, etkilerse nasıl etkiler?

16. Kolanızın daha uzun süre soğuk kalması için küp, silindir, daire şeklindeki buz parçalarından hangisini tercih edersiniz?

17. Buz parçalarının erime süresine etkileyen faktörler nelerdir? 
Yukarıda verilen sorular kullanılarak öğrencilerin konu ile ilgili düșünceleri ortaya çıkarılır. Bu süreçte öğrenciler rahatlıkla düşüncelerini açıklayabilecekleri, anlașılmayan ifadeleri rahatlıkla dile getirebilecekleri, farklı görüşler ortaya koyabilecekleri ve düşüncelerini gerekçeleriyle açıkladıkları interaktif/diyaloglu bir etkileşimin olduğu bir öğrenme ortamı oluşturulur. Bu süreçte konunu günlük yaşamla ilişkilendirilmesi olay ve olguların oluş sebeplerin sorgulanması önemlidir. Öğrencilerden gelen fikirleri seçerek anahtar kavramların tahtaya yazılması önerilir.

$\mathrm{Bu}$ süreçte, öğretmen-öğrenci ve öğrenciler arasında interaktif diyaloglu bir etkileşimi sürdürmek için öğretmen öğrencilerin düşüncelerini paylaşması için "Ne oldu?” "Bu konudaki düşünceniz nedir?”, "Ne düşünüyorsunuz?” "Ne iddia ediyorsun?" șeklinde sorular yöneltilebilir. Öğrenciler düșüncelerini paylaștıktan nedenlerini açlklaması için "Böyle olmasın nedeni ne olabilir?”, “ Neden böyle düşünüyorsun?” “Niçin böyle düşündün?” gibi sorular yönelterek gerekçeler olușturmaları ve neden-sonuç ilișkileri kurmaları sağlanabilir. Öğrencilerin birbirini dinlemesi için "Arkadașınız ne dedi?”, Arkadaşınızın dediğini kim toparlayacak?" gibi sorular yöneltilebilir. Yapılan açıklamaların doğruluğunun sorgulanması için "Sizce doğru mu?", "Böyle değil diyen var mı?", "İtirazı olan var mı?", "Aksini iddia eden var mı?" şeklinde sorular sorulabilir. Farklı açıklamaların üretilmesi için "Farklı düşünen var mı?", "Başka açılklaması olan var mı?”, "Eklemek isteyen var mı?”, "Farklı bir şey söylemek isteyen var mı?”, “Bu konuda siz ne düşünüyorsunuz?”, "Sizin fikriniz ne? gibi sorular yöneltilerek öğrencilerin çekinmeden fikrini açılaması sağlanmalıdır.

Dersin birinci aşamasında kazandırılması hedeflenen 21. yüzyıl becerileri; bilimsel akıl yürütme, yansıtıcı düşünme, üstbilişsel farkındalık, eleştirel düşünme, sorgulayıcı düşünme, bilimsel iletişim becerileridir.

\section{Așama: Argümantasyon Destekli Araştırma sorgulamaya Dayalı Etkinlik Tasarlama}

$\mathrm{Bu}$ aşamada, öğrencilerin kendi deneyini kendilerinin tasarlaması ve yapması, elde ettikleri verilere dayalı olarak akıl yürütmeleri ve verilerden soyut çıkarımlar yapabilmeleri amaçlanmaktadır.

Öğrenciler bu etkinlikte erime ve çözünmeyi etkileyen faktörleri araștırmak için deney tasarlayacak ve düzenleyecektir. Her bir grubun farklı bir faktörü araștırmaları ve bununla ilgili deney tasarlamaları sağlanır. Örneğin birinci grup, sıcaklığın çözünmeye etkisini araştırır. İkinci grup, sıcaklığın çözünme hızına etkisini araștırır. Üçüncü grup, çözücü cinsinin çözünmeye etkisini araştırır. Dördüncü grup çözünenin cinsinin değişmesinin çözünmeye etkisini araştırır. Beşinci grup, karıştırmanın çözünme hızına etki edip etmediğini araştırır. Altıncı grup, Çözünen maddenin temas yüzeyinin çözünme hızına etkisi olup olmadı̆̆ının araștırır. Yedinci grup, Buz parçalarının șeklinin erime süresine etkisini araştırır. Sekizinci grup ise, buz parçaları üzerine dökülen maddelerin erime süresini nasıl etkilediğini araştırır.

Öğretmen grupların araştırma sorularını belirlemelerine rehberlik eder ve bu süreçte öğrencilere yönlendirici sorular sorar ve araştırma sürecinde öğretmen adaylarına yardımcı olur. Her grup araştırma sorusunu kendileri oluşturur ve grup arkadașları ile tartıșarak araștırma sorularını nasıl bir test edeceklerine bunun için nasıl bir deney tasarlayacaklarına kendileri karar verirler. Așağıda belirtilen araç ve gereçler öğrencilere sunulur. Her grup ihtiyacı olan malzemeyi kendileri belirler. Bu aşamada öğretmen her grup ile etkileşimde bulunur ve grupların ihtiyacı olduğu noktalarda onlara rehberlik eder. Öğrenciler araştırmanın başından sonuna kadar grubun aktif üyesi olarak yer alır.

Bu süreçte öğretmen gruplara "Bu konuda neleri merak ediyorsunuz? Neyi araștırmak istiyorsunuz?", "Bu soruyu nasıl sormalısın ki araştırılabilir bir soru olsun?", "Buradaki bağımlı ve bağımsız değiş̧kenleriniz neler?”, "Hangi değișkenleri sabit tutmanız gerekiyor?", "Sizce ne olacak?", "Bilimsel bilginizi kullanarak bunu açıklayabilir misiniz?", "Araștırma sorunuzu test etmeniz için hangi malzemelere ihtiyacınız var?", "Güvenlik için nelere dikkat etmeniz gerekiyor?", "Araştırma sorunuzu test etmek için nasıl bir deney yapacaksınız?", "Güvenilir sonuçlar elde etmeniz için neye ihtiyacınız var?", "Ne tür veriler elde ettiniz?", "Verinizi nasıl sunacaksınız?", "bulduklarınız sonucunda neyi iddia ediyorsunuz?", "iddianızı destekleyen delilleriniz neler?”, “Araștırmanızda hata kaynakları neler olabilir?” gibi yönlendirici sorularla süreç boyunca öğrencilere rehberlik edilebilir.

Dersin ikinci așamasında kazandırılması hedeflenen 21. yüzyıl becerileri; bilimsel süreç becerileri, bilimsel akıl yürütme, bilimsel düşünme, eleştirel düşünme, iş birlikli çalışma, üstbilişsel farkındalık, yansıtıcı düşünme ve yaratıcı düșünme becerileridir.

Gerekli Araç-Gereçler: Sıcak ve soğuk su, gıda boyası, mürekkep, beher, farklı şekillerde aynı miktarlarda buz parçacıkları, tuz, kabartma tozu, karbonat, pudra şekeri, küp şeker, toz şeker, alka-seltzer tablet, naftalin, sirke, alkol, hassas terazi, karıștırıcı

\section{Așama: Yapılan Deneylerin Sunulması/Büyük Grup Tartışması}

Son aşamada, öğrencilerin elde ettikleri sonuçları bilimsel terminolojiyi kullanarak açıklamaları ve araştırma süreci içindeki hataları tanımlamak böylece hataların düzeltilmesi amaçlanmaktadır.

Her grup tasarladığı deneyi sınıfa sunar. Sunumları sırasında araştırma sorularına, değiștirdiği ve kontrol ettikleri değișkenlere, deney sonucunda neyi iddia ettiklerine ve delillerinin neler olduğuna yer verilir. Elde ettikleri deney ve gözlem sonuçlarını bilimsel kavramlarla ilişkilendirmeleri ve açıklamalarına rehberlik edilir. İddianın içeriği, iddiayı 
desteklemek için kullanılan delillerin kalitesi ve gerekçelendirmesinin gücü değerlendirilir. Araştırma soruları benzer olan grupların sonuçları karşılaştırılır, benzerlik ve farklılıkları üzerinden tartışılır. Deney sonuçlarını bilimsel terminolojiyi kullanarak sunmalarına rehberlik edilir.

Dersin üçüncü aşamasında büyük grup tartışmaları sırasında sunum yapan kişiye "Bu verileri nasıl elde ettiniz?", "Topladığınız verilerin güvenilir olduğundan emin olmak için ne yaptınız?", "Elde ettiğini verileri nasıl analiz ettiniz?", "Neden kanıtlarınızı bu şekilde sunmaya karar verdiniz?”, "Grubunuzun iddiası doğru mu sizce?”, "iddianızdan ne kadar eminsiniz?" ş̧eklinde sorular yöneltilerek en geçerli veya kabul edilebilir cevabı geliștirmeleri sağlanabilir.

Dersin üçüncü așamasında kazandırılması hedeflenen 21. Yüzyıl becerileri; bilimsel iletișim, üstbilișsel farkındalık, bilimsel akıl yürütme, eleștirel düșünme, sorgulayıcı düşünme becerileri ve bilimin doğası anlayışlarının gelișmesidir. 